\title{
Surveys for \\ Animal Species of Concern in Northwestern Montana
}

\author{
Prepared for: \\ Montana Department of Fish, Wildlife \& Parks \\ State Wildlife Grants Program \\ Helena, Montana \\ Compiled By: \\ Paul Hendricks \\ Montana Natural Heritage Program \\ Natural Resource Information System \\ Montana State Library
}

May 2005

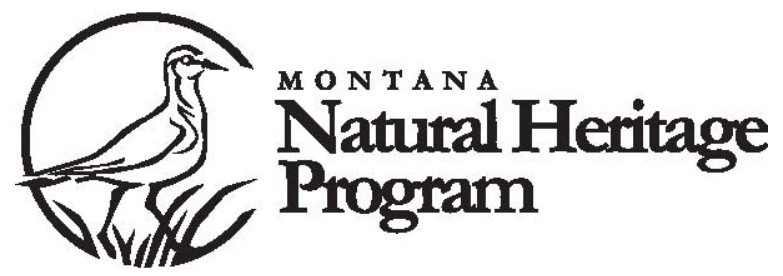




\title{
Surveys for Animal Species of Concern in Northwestern Montana
}

\author{
Prepared for: \\ Montana Department of Fish, Wildlife and Parks \\ State Wildlife Grants Program \\ Helena, Montana
}

Compiled By:

Paul Hendricks

Montana Natural Heritage Program

Natural Resource Information System

Montana State Library

May 2005

(C) 2005 Montana Natural Heritage Program

P.O. Box 201800, 1515 East Sixth Avenue, Helena, MT 59620-1800, 406-444-3655 
This document should be cited as follows:

Hendricks, P., Compiler. 2005. Surveys for Animal Species of Concern in Northwestern Montana. Report to Montana Department of Fish, Wildlife, and Parks, State Wildlife Grants Program, Helena, Montana. Montana Natural Heritage Program, Helena, MT. 53 pp. 


\section{ABSTRACT}

From late summer 2003 through autumn of 2004, surveys for a diversity of Animal Species of Concern in western Montana were made possible by a grant from the State Wildlife Grants Program administered by Montana Department of Fish, Wildlife and Parks (MTFWP). Included were stream surveys for the Harlequin Duck (Histrionicus histrionicus), waterfall surveys for nesting Black Swift (Cypseloides niger), seepage and stream surveys for Coeur d'Alene Salamander (Plethodon idahoensis), surveys in cedar-hemlock-grand fir forests for rare terrestrial mollusks (snails and slugs), and surveys for forest owls and rare terrestrial mollusks on Plum Creek Timber Company lands.

Surveys for Harlequin Ducks were conducted on 22 streams in eight drainage systems, and ducks were found on seven streams in five drainage systems. Twenty individuals were captured and banded. Numbers of pairs and broods on 5 streams in the Lower Clark Fork drainage were at or below minimums documented during the prior eight-year period (1992-1999) of monitoring. However, numbers of pairs and/or broods on other surveyed streams were at or above average. Streams of the Lower Clark Fork drainage may experience more extreme responses in stream flows to on-going drought relative to some other streams, such as Upper McDonald Creek in Glacier National Park.

Surveys of 32 potential Black Swift nesting sites (water falls) in northwestern Montana represented the first organized nesting survey for this species in the state. Only two nesting sites were known at the time of the surveys; nesting was confirmed at one of these (South Fork Mission Creek), and one new site was found on Haystack Creek in Glacier National Park. The numbers of swifts visiting these falls do not account for numbers seen annually across the state, indicating that more breeding sites await discovery.

Eight historical Coeur d'Alene Salamander sites were visited one or more times in 2004; only one of these sites had been checked since 1995. Salamanders were found at five sites, all with surface water flow at the time of the visit; the other three sites were dry at the time of the visit (early September). Continued presence of Coeur d'Alene Salamanders at all sites with surface water flow suggests that this species probably persists at most or all of the previously documented locations in Montana.

Surveys for globally rare mollusks associated with cedar-hemlock-grand fir forests were conducted concurrent with salamander surveys. Five species (Polygyrella polygyrella, Radiodiscus abietum, Magnipelta mycophaga, Hemphillia danielsi, Prophysaon humile), documented in Montana at 1-13 locations each as of 2003, were found at ten total locations, nine of which were new. This vulnerable forest habitat deserves special protection to conserve the suite of associated rare mollusk species.

Forest Owl surveys on Plum Creek lands in three areas of ponderosa pine-dominated forest resulted in detection of four species, including a nest of Great Gray Owl (Strix nebulosa); no Flammulated Owls (Otus flammeolus) were detected. Two species of globally rare mollusks (Magnipelta mycophaga, Oreohelix elrodi) were found at one site each during invertebrate surveys; the Magnipelta location in Flathead County was new, one of only 13 documented for Montana. 


\section{TABLE OF CONTENTS}

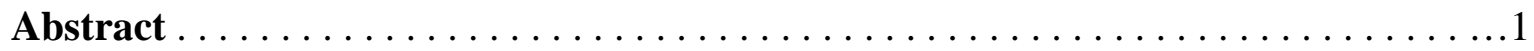

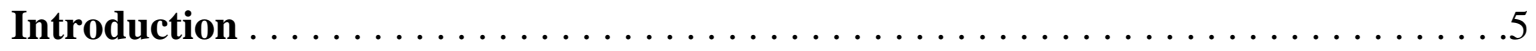

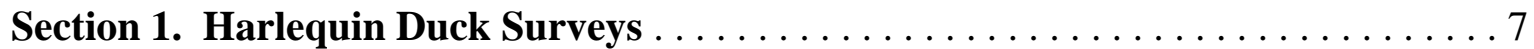

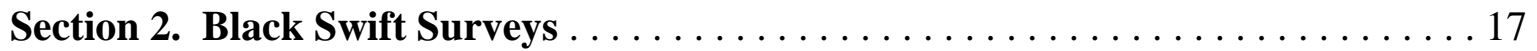

Section 3. Coeur d'Alene Salamander Surveys $\ldots \ldots \ldots \ldots \ldots \ldots \ldots \ldots \ldots \ldots \ldots$

Section 4. Terrestrial Mollusk Surveys $\ldots \ldots \ldots \ldots \ldots \ldots \ldots \ldots \ldots \ldots \ldots$

Section 5. Plum Creek Owl and Mollusk Surveys . . . . . . . . . . . . . . . . . .45 


\section{INTRODUCTION}

An initial step to evaluating the status and conservation needs of animal Species of Concern in Montana is to document their distributions and habitat associations. Status of the species addressed in this document is unknown or incomplete, and sometimes based on data that is old. Initial surveys have been conducted for some species, such as Harlequin Duck (Histrionicus histrionicus), Flammulated Owl (Otus flammeolus), and Coeur d'Alene Salamander (Plethodon idahoensis). However, continued monitoring and additional surveys of these species have not always occurred and past efforts are in jeopardy of being wasted because of a lack of follow-up inventory and monitoring. For other species, such as Black Swift (Cypseloides niger), no prior organized survey effort in Montana has ever occurred. And invertebrates continue to receive relatively little attention, even though they comprise the greatest division of animal biodiversity in Montana; even the invertebrate species recognized as globally rare have distributions and habitat associations in Montana that are incomplete and poorly understood.

The impetus for this blanket project was to document the distribution and habitat associations of a variety of animal Species of Concern in western Montana and to better define the range of these species in the state. The data gathered help provide managers information they need to assess the effects of management activities on a broader range of animals of conservation concern, and also provide information to help establish priorities for the Comprehensive State Wildlife Plan. The results of this project thus add to information needed for effective long-term conservation of the target species.

This document contains five separate reports ("Sections") on Animal Species of Concern in western Montana. These individual projects were designed to address gaps in our knowledge about forest-inhabiting species. Targeted species of conservation interest included Harlequin Duck (G4, S2B), Black Swift (G4, S3B), Flammulated Owl (G4, S3B), Coeur d'Alene Salamander (G4, S2), and a suite of globally rare terrestrial mollusks (all ranked between G1, S1 and G2G3, S1S3).

Funding for this project was provided to the Montana Natural Heritage Program by the Montana Department of Fish, Wildlife, \& Parks through the State Wildlife Grants Program. The State Wildlife Grants (SWG) program was created by congressionally appropriated funds to assist states in the development and implementation of programs that benefit wildlife and their habitats. Field results from all surveys have been incorporated into the Point Observation Database (POD) and the Montana Natural Heritage Program's Biotics 4 conservation information data system. Updated location and natural history information are available through the MTNHP web site. 


\section{SECTION 1}

\section{HARLEQUIN DUCK SURVEYS}




\title{
Harlequin Duck Surveys in Northwestern Montana: 2003-2004
}

\author{
Paul Hendricks \\ Montana Natural Heritage Program
}

\section{Introduction}

The Harlequin Duck (Histrionicus histrionicus) is a small sea duck, which travels inland to breed on fresh water streams (Robertson and Goudie 1999). Approximately 150-200 pairs of Harlequins currently breed in Montana (Reichel et al. 1997), with most located in the following areas: 1) tributaries of the lower Clark Fork River; 2) tributaries of the North, Middle, and South Forks of the Flathead River; 3) streams coming off the east front of the Rocky Mountains; and 4) the Boulder River.

Most ducks arrive on their inland breeding areas in mid-April to early-May; unmated males typically arrive before pairs (Kuchel 1977). The males return to the coast shortly after the females begin incubation; most are gone by early July (Kuchel 1977). The females and young remain on the streams until August or early September. This chronology is influenced by elevation and by the timing of spring runoff; it may vary up to several weeks between years.

The Harlequin Duck is listed as "Sensitive" by the U.S. Forest Service, Region 1 and as an Animal Species of Concern by the Montana Natural Heritage Program and Montana Department of Fish, Wildlife, \& Parks (Montana Natural Heritage Program 2004).

The Montana Natural Heritage Program began banding Harlequin Ducks to a limited extent in 1991. Through 1999, a total of 391 Harlequin Ducks were marked on 9 streams, representing the largest marked "population" from the breeding streams (Hendricks 2000). Birds marked in Montana have subsequently been captured and observed on the coasts of Alaska, Oregon, Washington and British Columbia, with most reports coming from the Vancouver Island area (Reichel et al. 1997, Hendricks 2000).

Objectives for the 2003-2004 seasons included 1) surveying the Lower Clark Fork streams (Rock Creek, Marten Creek, South Fork Marten Creek, Swamp Creek, Vermilion River) of Sanders County for presence and status of Harlequin Ducks, 2) gathering duck productivity data on the Lower Clark Fork streams, 3) marking as many individuals as feasible on these streams for long-term monitoring, 4) surveying McDonald Creek in Glacier National Park, the only other population in Montana with survey data comparable to the Lower Clark Fork population, and 5) surveying a total of 20 streams in the northwestern region of Montana for Harlequin Duck presence and productivity, to obtain a better picture of current status in this area.

This report summarizes the results of the 2003-2004 surveys. For a recent and relatively comprehensive summary of Harlequin Duck research in Montana through 1999 see Hendricks (2000).

\section{Methods}

As part of a regional survey of Harlequin Ducks in northwestern Montana during 2003-2004, Heritage zoologists, with support and assistance from NPS personnel and others (see Acknowledgments), conducted May pair surveys and late-July 
and August brood surveys in the Lower Clark Fork set of streams and in Glacier National Park, with special attention to Upper McDonald Creek. Also in Glacier National Park, pair surveys were conducted on Fish and Fern creeks near the southwest end of McDonald Lake, and brood surveys on upper St. Mary River, and Reynolds and Paradise creeks east of Logan Pass. Elsewhere, brood surveys were conducted on an additional 12 streams in the Middle Clark Fork River, South, Middle, and North Fork Flathead River, Stillwater River (north), and North Fork Blackfoot River drainages (Table 1).

Surveys were conducted by walking the stream channel (when possible) or stream bank. In most cases, the surveyor walked upstream, giving more time to observe the bird before it moved out of sight; in cases where birds were not to be marked, the surveyor made a loop around the birds to minimize disturbance. We attempted to capture and mark all birds seen when a licensed, qualified bird bander was present on the survey, and when the conditions were considered safe for banding. Park personnel monitored Upper McDonald Creek between McDonald Lake and Logan Creek both before and after Heritage personnel participated in pair and brood surveys in 2004 (see Richards and Edmonds 2004).

Captured birds were sexed, aged, weighed, measured (wing chord and tail), marked, and released. Juveniles were aged based on feather development: Class IA-C: downy (114 days old), no feathers visible; Class IIAC: partly feathered (15-35 days old); Class III: fully feathered but flightless (36-51 days old). Each captured bird was banded with a USFWS aluminum band and a blue plastic leg band with 2 white alpha-alpha (juveniles) or alpha-numeric (adults) characters. Thus birds are individually recognizable by the imprinted characters on their bands. Dates, locations, distance surveyed, and general characteristics of the stream reaches surveyed were recorded; location, number, age, and sex of all Harlequin Ducks seen were recorded, as were habitat characteristics of the sites where ducks were first observed. All surveys and duck observations were entered into the Heritage Biotics database.

\section{Results}

Surveys in 2003-2004 were conducted in eight "drainage systems" as delimited in Reichel et al. (1997); Harlequin Ducks were observed in five of these (Table 1). Only brood surveys were conducted on surveyed streams in 2003, whereas in 2004 both pair and brood surveys were conducted on two focal drainages (Lower Clark Fork and Upper McDonald Creek), in addition to brood surveys on other streams. Only Fish and Fern creeks (Glacier National Park) experienced pair surveys with no brood surveys in 2004.

In 2003, Harlequin Ducks were observed during brood season in the Lower Clark Fork drainage (one brood of 2) and South Fork Flathead River drainage (three broods of 6,5 , and 5 young and their hens; two single females). In 2004, ducks were seen during pair season in the Lower Clark Fork drainage (one pair, but at least two more pairs missed) and Glacier National Park (11 pairs and 10 males). During brood season, ducks were seen in the Lower Clark Fork drainage (two broods of 4 and 6 young plus their hens), Glacier National Park (four broods of 3, 3, 5, and 7 young plus three hens; a fifth brood was reported), North Fork Flathead River (two broods of 4 and 5 young plus their hens), and North Fork Blackfoot River (one brood of 8 young plus their hen). Results of surveys in each drainage system are summarized below.

Lower Clark Fork: Five streams of this drainage were surveyed three times: South Fork Marten Creek, Marten Creek, Rock Creek, Swamp Creek, and Vermilion River. 
Segments surveyed were those covered on previous visits (see Reichel et al. 1997, Hendricks 2000). In 2003 only brood surveys were conducted, and only one brood of two young, on Marten Creek, was observed and banded (Table 2). In 2004, only one pair was seen in spring on this suite of streams, on Marten Creek. However, two broods (of 4 and 6 young) with hens were observed on Rock Creek during the brood surveys of 2004, indicating two pairs were missed in spring (because they were overlooked, the pair surveys were too early, or the pairs had already disbanded). One of the Rock Creek broods was captured and banded (Table 2). Stream flows during all surveys were relatively low, and total numbers of females and broods were also at or below the long-term (1992-1999) minimums for this group of streams (Hendricks 2000).

Middle Clark Fork: One stream, Cache Creek, was surveyed along the standard section during the 2004 brood season. No Harlequin Ducks were observed. This stream has been surveyed only infrequently, but pairs have been documented previously (Reichel et al. 1997).

Glacier National Park: Under this heading are two drainages that were surveyed: McDonald Creek and Upper Saint Mary River. Streams surveyed in 2004 within each were Upper McDonald, Fish, and Fern creeks in the first, and Upper Saint Mary River, Reynolds, and Paradise creeks in the second. Only Upper McDonald Creek was surveyed during both the pair and brood seasons (Table 1 ). Ten pairs and ten single males (30 birds total) were observed on Upper McDonald Creek in early May, a near record count. During brood surveys in late August, three broods (of 3, 5, and 3 young) were captured and banded (Table 2). A fourth brood of 7 young with a hen was observed five days later; none of these birds was already banded. Thus, four broods (18 young) were observed on McDonald Creek in August 2004. The three broods banded on 20 August and a fourth unbanded brood seen on 25 August are probably the same ones documented during an 11 August survey by Park personnel (see Richards and Edmonds 2004).

No Harlequin Ducks were observed on the other streams surveyed in the Park, except for a pair in May on Fish Creek. Reports of a brood in this area, well before the brood surveys were conducted on Upper McDonald Creek, suggest that the Fish Creek pair produced a brood (Steve Gniadek personal communication).

South Fork Flathead: Three streams in this drainage were surveyed, all in late July 2003 (Table 1). Three broods (of 6, 5, and 5 young) and their hens, plus a lone female, were encountered on Spotted Bear River, and a lone female was seen on Sullivan Creek. These numbers are comparable to brood survey results of these streams in previous years (Hendricks and Reichel 1998). No Harlequin Ducks were observed on Wounded Buck Creek, although they have bred on this stream in the past (Reichel et al. 1997).

Middle Fork Flathead: Five streams in this drainage were surveyed, all in brood season 2003 (Table 1). No Harlequin Ducks were observed on any of these. Two streams (Middle Fork Flathead River and Granite Creek) have had prior reports of ducks, but breeding status on them remains uncertain (Reichel et al. 1997). The three remaining streams (Shaefer Creek, Dolly Varden Creek, and Morrison Creek) are considered potential breeding streams, but with no prior records of Harlequin Ducks; each had been surveyed no more than twice prior to 2003.

North Fork Flathead: One stream, Trail Creek, was surveyed along the standard section during brood season of 2004. Two broods (4 and 5 young) and their hens were observed (Table 1). The surveyed section of 
Trail Creek is an island of forest within a larger region completely denuded by fire in summer 2003. One to three broods are typical for this creek (Reichel et al. 1997, Hendricks and Reichel 1998, Hendricks 1999). It is encouraging that Harlequin Ducks continue to breed successfully on this creek despite an obvious increase of sediment deposited in the streambed.

Stillwater (N): One stream, Swift Creek, was surveyed during brood season 2003 in this drainage in the Whitefish area (Table 1). No Harlequin Ducks were observed. Swift Creek is considered a stream probably used by Harlequin Ducks for breeding (Reichel et al. 1997). However, breeding has not yet been documented despite four prior surveys.

North Fork Blackfoot: One stream, North Fork Blackfoot River, was surveyed in this drainage along the standard section during brood season 2004 (Table 1). One brood (8 young) and their hen were observed. Few prior surveys have been conducted on this stream, but pairs and broods are regularly reported (Reichel et al. 1997), and a few birds have been captured and banded. 
Table 1. Streams surveyed for Harlequin Ducks during 2003-2004. Watersheds, as delimited in Reichel et al. (1977), are in bold type.

\begin{tabular}{|c|c|c|c|c|c|c|}
\hline Stream & Date & Pairs & Males & Females & Broods & Young \\
\hline \multirow{4}{*}{$\begin{array}{l}\text { Lower Clark Fork } \\
\text { South Fork Marten Cr. }\end{array}$} & & & & & & \\
\hline & 26 Jul. 2003 & 0 & 0 & 0 & 0 & 0 \\
\hline & 3 May 2004 & 0 & 0 & 0 & 0 & 0 \\
\hline & 26 Jul. 2004 & 0 & 0 & 0 & 0 & 0 \\
\hline \multirow[t]{3}{*}{ Marten Cr. } & 27 Jul. 2003 & 0 & 0 & 0 & 1 & 2 \\
\hline & 4 May 2004 & 1 & 1 & 1 & 0 & 0 \\
\hline & 26 Jul. 2004 & 0 & 0 & 0 & 0 & 0 \\
\hline \multirow{3}{*}{ Rock Cr. } & 28 Jul. 2003 & 0 & 0 & 0 & 0 & 0 \\
\hline & 5 May 2004 & 0 & 0 & 0 & 0 & 0 \\
\hline & 27 Jul. 2004 & 0 & 0 & 2 & 2 & 10 \\
\hline \multirow[t]{3}{*}{ Swamp Cr. } & 30 Jul. 2003 & 0 & 0 & 0 & 0 & 0 \\
\hline & 6 May 2004 & 0 & 0 & 0 & 0 & 0 \\
\hline & 28 Jul. 2004 & 0 & 0 & 0 & 0 & 0 \\
\hline \multirow[t]{3}{*}{ Vermilion R. } & 29 Jul. 2003 & 0 & 0 & 0 & 0 & 0 \\
\hline & 7 May 2004 & 0 & 0 & 0 & 0 & 0 \\
\hline & 28 Jul. 2004 & 0 & 0 & 0 & 0 & 0 \\
\hline \multicolumn{7}{|l|}{ Middle Clark Fork } \\
\hline Cache Cr. & 27 Aug. 2004 & 0 & 0 & 0 & 0 & 0 \\
\hline \multicolumn{7}{|l|}{ Glacier National Park } \\
\hline \multirow[t]{4}{*}{ Upper McDonald Cr. } & 9 May 2004 & 10 & 20 & 10 & 0 & 0 \\
\hline & 31 Jul. 2004 & 0 & 0 & 0 & 0 & 0 \\
\hline & 20 Aug. 2004 & 0 & 0 & 2 & 3 & 11 \\
\hline & 25 Aug. 2004 & 0 & 0 & 1 & 1 & 7 \\
\hline Fern Cr. & 10 May 2004 & 0 & 0 & 0 & 0 & 0 \\
\hline Fish Cr. & 10 May 2004 & 1 & 1 & 1 & 0 & 0 \\
\hline Paradise Cr. & 5 Aug. 2004 & 0 & 0 & 0 & 0 & 0 \\
\hline Reynolds Cr. & 4 Aug. 2004 & 0 & 0 & 0 & 0 & 0 \\
\hline Upper St. Mary R. & 4 Aug. 2004 & 0 & 0 & 0 & 0 & 0 \\
\hline \multicolumn{7}{|l|}{ South Fork Flathead } \\
\hline Spotted Bear R. & 26 Jul. 2003 & 0 & 0 & 4 & 3 & 16 \\
\hline Sullivan Cr. & 24 Jul. 2003 & 0 & 0 & 1 & 0 & 0 \\
\hline Wounded Buck Cr. & 23 Jul. 2003 & 0 & 0 & 0 & 0 & 0 \\
\hline \multicolumn{7}{|l|}{ Middle Fork Flathead } \\
\hline Middle Fork Flathead R. & 27 Jul. 2003 & 0 & 0 & 0 & 0 & 0 \\
\hline Granite Cr. & 9 Aug. 2003 & 0 & 0 & 0 & 0 & 0 \\
\hline Shaefer Cr. & 8 Aug. 2003 & 0 & 0 & 0 & 0 & 0 \\
\hline Dolly Varden Cr. & 7 Aug. 2003 & 0 & 0 & 0 & 0 & 0 \\
\hline Morrison Cr. & 5 Aug. 2003 & 0 & 0 & 0 & 0 & 0 \\
\hline $\begin{array}{l}\text { North Fork Flathead } \\
\text { Trail Cr. }\end{array}$ & 30 Jul. 2004 & 0 & 0 & 2 & 2 & 9 \\
\hline Stillwater (N) & 29 Aug. 2003 & 0 & 0 & 0 & 0 & 0 \\
\hline $\begin{array}{l}\text { North Fork Blackfoot } \\
\text { North Fork Blackfoot R. }\end{array}$ & 18 Aug. 2004 & 0 & 0 & 1 & 1 & 8 \\
\hline
\end{tabular}


Table 2. Harlequin Ducks captured and banded on Marten Creek ("Marten”) on 26 July 2003, Rock Creek ("Rock") on 27 July 2004, and Upper McDonald Creek ("McDonald") on 20 August 2004. All color bands are blue with white alpha-alpha (juvenile) or alpha-numeric (adult) codes.

\begin{tabular}{|c|c|c|c|c|c|c|}
\hline $\begin{array}{c}\text { Aluminum Band } \\
\text { No. }\end{array}$ & $\begin{array}{c}\text { Color Band } \\
\text { Code }\end{array}$ & Sex $^{\mathbf{a}}$ & Age $^{\mathbf{b}}$ & $\begin{array}{c}\text { Weight } \\
\text { (g) }\end{array}$ & $\begin{array}{c}\text { Wing Chord } \\
\text { (mm) }\end{array}$ & $\begin{array}{c}\text { Tail Length } \\
\text { (mm) }\end{array}$ \\
\hline Marten: Group 1 & & & & & & \\
$925-72611$ & RF & U & IIC & 540 & 168 & 75 \\
$925-72612$ & RD & U & IIC & 435 & 152 & 70 \\
\hline Rock: Group 1 & & & & & & \\
$925-72613$ & TV & U & IIB & 500 & 138 & 68 \\
$925-72614$ & TW & U & IIB & 450 & 132 & 66 \\
$925-72615$ & T4 & F & ASY & 510 & 189 & 88 \\
$925-72616$ & TX & U & IIB & 470 & 132 & 64 \\
$925-72617$ & TY & U & IIB & 425 & 132 & 64 \\
\hline McDonald: Group 1 & & & & & & \\
$925-72618$ & GR & U & FJ & 580 & 169 & 78 \\
$925-72619$ & G6 & F & ASY & 620 & 181 & 78 \\
$925-72620$ & GT & U & FJ & 560 & 171 & 71 \\
$925-72624$ & GS & U & FJ & 540 & 162 & 67 \\
\hline McDonald: Group 2 & & & & & & \\
$925-72625$ & GW & F & III & 450 & 155 & 72 \\
$925-72626$ & GV & M & III & 520 & 156 & 75 \\
$925-72627$ & GZ & M & III & 540 & 157 & 77 \\
$925-72628$ & GY & M & III & 530 & 160 & 74 \\
$925-72629$ & GX & F & III & 510 & 151 & 75 \\
\hline 925-72630 & G7 & F & ASY & 600 & 195 & 77 \\
$925-72631$ & BA & M & FJ & 560 & 181 & 73 \\
$925-72632$ & BX & F & FJ & 490 & 176 & 68 \\
$925-72633$ & BJ & F & FJ & 470 & 168 & 68 \\
\hline McDonald: Group 3
\end{tabular}

${ }^{\mathrm{a}} \mathrm{F}=$ female, $\mathrm{M}=$ male, $\mathrm{U}=$ undetermined.

${ }^{\mathrm{b}}$ IIB = juvenile with down on back and posterior half of body, IIC = juvenile with down confined to lower back and vent, III = juvenile fully feathered but flightless, FJ = flying juvenile, ASY $=$ after second year adult. 


\section{Discussion}

The maximum one-day count of pairs (ten) in 2004, and the total brood count (four), were the largest for Upper McDonald Creek since 1997 and 1992, respectively (Richards and Edmonds 2004). The brood counts in 2004 on McDonald Creek are more encouraging for Harlequin Duck productivity in Montana than those on the five monitored Lower Clark Fork streams in the Noxon area, which apparently produced only two broods in 2004 (the eight-year average for the period 19921999 was 4.6 broods; Hendricks 2000). Thus it seems that "good" years and "bad" years for Harlequin Ducks are not necessarily synchronized across northwestern Montana.

McDonald Creek continues to be an important breeding stream in Montana for Harlequin Ducks. Stream flow levels are maintained through the brood season at levels sufficient over much of the full reach of Upper McDonald Creek to be utilized by ducks until ducklings are old enough to move downstream and disperse. In contrast, tributary streams of the Lower Clark Fork River near Noxon and Trout Creek often experience August water levels so low that the beds go dry in some areas where breeding by Harlequin Ducks appears to occur (personal observation). Low water levels may make Harlequin broods more susceptible to predation, and may reduce available food levels to the point where deleterious effects are apparent on duckling survival. Thus, the available time-series data suggest that McDonald Creek may be more reliable Harlequin Duck breeding habitat, whereas Harlequins breeding on the streams in the Noxon area are exposing themselves to marginal habitat in some years.

Other Harlequin Duck breeding streams in northwestern Montana that were surveyed during 2003-2004 showed about average productivity relative to prior survey results (Reichel et al. 1997, Hendricks and Reichel
1998, Hendricks 1999, 2000). Results from Spotted Bear River, Trail Creek, and North

Fork Blackfoot River (in three distinct drainages) are especially encouraging and suggest that ducks continue to do as well on these streams as they did a decade ago. The results from these drainages, seemingly consistent with trends on Upper McDonald Creek, further underscore the disappointing results from the Lower Clark Fork streams. Thus, it is unlikely that events on the wintering areas are affecting the apparent decline of the Lower Clark Fork population, because Harlequins from many Montana breeding streams (including all of those surveyed in 2003-2004) intermix on the Pacific coast during winter.

The results from the 2003-2004 field seasons indicate a need for sustained monitoring on all of the above streams, so that the Lower Clark Fork results can be placed in a larger regional context of population trends, and interpreted appropriately. There is also a need to understand why the apparent decline of breeding in the Noxon area is happening. This will require monitoring stream flows (there appears to be a correlation between the recent years of drought and the decline in productivity) and benthic productivity (especially those taxa fed upon by Harlequin Ducks) on selected streams, and analyzing trends of each. Analyses of surrounding landscapes are also important so that other types of large-scale disturbances can be eliminated as factors contributing to population trends; we still don't fully understand what drives Harlequin Duck populations up or down. 


\section{Acknowledgements}

Many people participated in Harlequin Duck stream surveys during 2003-2004, including Susan Leonard, Coburn Currier, Martin Miller, and Joe Johnson (all with Montana Natural Heritage Program), John Carlson (formerly with Heritage), Eric Dobbs (on contract with Heritage in 2003), Jim Sparks (BLM Missoula Field Office), Amy Edmonds, Pete Lumberg, John Kyle, Steve Rice, and Steve Gniadek (all affiliated with Glacier National Park), and Cyndi Smith (Waterton Lakes National Park, Canada), who educated us all on some fine points of Harlequin Duck biology. I apologize to those whose names I overlooked; your help with the surveys is appreciated nevertheless.

\section{Literature Cited}

Hendricks, P. 1999. Harlequin Duck research and monitoring in Montana: 1998. Montana Natural Heritage Program. Helena, MT. 30 pp.

Hendricks, P. 2000. Harlequin Duck research and monitoring in Montana: 1999. Montana Natural Heritage Program. Helena, MT. 34 pp.

Hendricks, P., and J. D. Reichel. 1998. Harlequin Duck research and monitoring in Montana: 1997. Montana Natural Heritage Program. Helena, MT. 28 pp.

Kuchel, C. R. 1977. Some aspects of the behavior and ecology of Harlequin Ducks breeding in Glacier National Park, Montana. M.S. thesis. University of Montana. Missoula, MT 160 pp.

Montana Natural Heritage Program. 2004. Montana Animal Species of Concern. MTNHP \& MFWP. Helena, MT. 13 pp.
Reichel, J. D., D. L. Genter, and D. P. Hendricks. 1997. Harlequin Duck research and monitoring in Montana:1996. Montana Natural Heritage Program. Helena, MT. 69 pp.

Richards, W., and A. Edmonds. 2004. Harlequin Duck surveys, Upper McDonald Creek, Glacier National Park. Chapter 1 in report to Glacier National Park, Division of Science and Resources Management. 11 pp.

Robertson, G. J., and R. I. Goudie. 1999. Harlequin Duck (Histrionicus histrionicus). In The Birds of North America, No. 466 (A. Poole and F. Gill, eds.). The Birds of North America, Inc. Philadelphia, PA. 32 pp. 


\section{SECTION 2}

\section{BLACK SWIFT SURVEYS}




\title{
Monitoring Black Swifts in Montana: 2004 Annual Report
}

\author{
Jeff Marks, Montana Audubon \\ Dan Casey, American Bird Conservancy
}

10 December 2004

\section{Summary}

The Black Swift (Cypseloides niger) is a poorly known species that is receiving increasing attention from the conservation community. Partners in Flight lists it as a Continental Watch List species and as a Priority Species in Bird Conservation Region 10 (officially, the Northern Rockies, which includes western Montana), the National Audubon Society also places it on their "WatchList," and the U.S. Fish and Wildlife Service recently listed it as a Species of Conservation Concern. It also has been designated as a Level II Priority Species in the Montana Bird Conservation Plan (Casey 2000).

From mid-July to late August 2004, we visited 32 potential nesting sites in western
Montana to initiate the first organized survey of nesting Black Swifts in the state. Prior to this work, Black Swifts had been documented nesting at only two sites in Montana (Hunter and Baldwin 1962, 1972). We confirmed that one of these historic sites was still active (South Fork Mission Creek); the other site (Mount Vaught/McPartland Mountain, Glacier National Park) most likely was not. We also found a new site in Glacier National Park (Haystack Creek) and learned of a possible new site in the Bitterroot Mountains (Gash Creek). Owing to a number of challenges discussed below, the surveys were difficult to conduct. Nonetheless, we are encouraged by our preliminary results and hope to undertake additional surveys in the coming years. 


\section{Methods}

Black Swifts are almost completely dependent on waterfalls for nesting (Knorr 1993, Marín 1997). We confined our surveys to waterfalls west of $110^{\circ}$ longitude because the species has not been recorded (breeding or otherwise) east of this longitude in Montana (Lenard et al. 2003).

Sites were visited by us and by qualified volunteers trained by us. Our main objective was to verify presence or absence of Black Swifts at each site. Secondarily, we wanted to estimate colony size at occupied sites. We also scored the suitability of each site (maximum score is 30, with higher values indicating higher suitability for nesting swifts) using protocols developed in Colorado, Oregon, and Washington (Schultz and Levad 2002, Altman 2003) and outlined by Casey (2004). These protocols are summarized on the field forms, a copy of which is presented in Appendix A.

Observers stationed themselves at the nearest safely accessible point that afforded a clear view of the waterfall and then simply watched for incoming swifts. We strived to be present for the last two hours before dusk at each site because Black Swifts typically concentrate their visits to nests at this time (Foerster and Collins 1990). We rated each falls during our visits to watch for swifts. Volunteers were briefed on procedures, and sometimes trained in the field, before conducting surveys of potential nesting sites.

\section{Results}

We visited 32 potential nesting sites in 2004, 12 in Glacier National Park, 3 on or adjacent to the Flathead National Forest, 2 in the Mission Mountains within the Flathead Reservation, 4 in the Bitterroot National Forest, and 11 in the Gallatin National Forest
(Table 1). We observed Black Swifts in the vicinity of five waterfalls in Glacier Park and one waterfall in the Mission Mountains; we watched them fly behind falls, presumably to nests, at two of these sites (see below). We found no active waterfall at the site near Mount Vaught/McPartland Mountain, where Black Swifts were first documented nesting in July 1962 (Hunter and Baldwin 1972), although additional waterfalls in the vicinity merit surveys in future years. The following narratives describe our 2004 survey efforts and results at all of the potential nesting sites we visited in 2004 . The ranking score recorded for each of the falls is listed in Table 1.

Appistoki Falls (Glacier Park).Visited by John and Kathy Hughes from 1900 to 2030 on 20 August. No swifts were seen.

Avalanche Lake complex (Glacier Park). - This series of falls on the headwall about $1.5 \mathrm{~km}$ above Avalanche Lake consists, from northeast to southwest, of Monument Falls and three unnamed falls, the last of which is due south of Avalanche Lake and just east of the Little Matterhorn. We (Dan Casey, Jeff Marks, Dick Cannings, and Steve Gniadek) observed all four falls from 1835-2100 on 12 July. Although we saw several Black Swifts (no more than two simultaneously) feeding above the lake and basin below the falls, we did not see them enter cliffs near the falls, or even approach the falls closely. Each of these falls is more than $200 \mathrm{~m}$ high, and they consist of a mixture of plunges, cascades, and horsetail sections. We observed them from $>1 \mathrm{~km}$ away, making it difficult to accurately assess features of the falls (height of different sections, moss and niche availability, etc.) and to see if swifts were approaching them. Parts of these falls appear to contain suitable habitat for nesting swifts, and the sites should 
be visited up close in future years. We note, however, that such surveys will require bushwhacking through dense, bear-infested habitat that would not be safe to traverse after sundown. Indeed, we retreated from our initial vantage point when an adult grizzly bear (Ursos arctos) appeared in the brush $250 \mathrm{~m}$ above Avalanche Lake and less than $150 \mathrm{~m}$ from us. We note that these waterfalls were surveyed for Black Swift nests in 1960, "without success" (Hunter and Baldwin 1962: 409).

Baring Falls (Glacier Park)._-Visited by John and Kathy Hughes from 1900 to 2030 on 21 August. No swifts were seen.

Bird Woman Falls (Glacier Park).Bird Woman Falls is an excellent example of a tall (ca. $125 \mathrm{~m}$ ) horsetail/plunge/fan falls. Dan Casey assessed it from $>3 \mathrm{~km}$ away through a spotting scope on 2 August. The falls seemingly are inaccessible for occupancy surveys, but they certainly offer suitable habitat, with strong flows of water late in the season, a commanding view, great aerial access, and what appear to be abundant and inaccessible (to predators) nesting niches. If one could figure out how to access this off-trail locale safely, it should be observed closely in the future because it offers strong potential as a nesting site for Black Swifts.

Haystack Creek (Glacier Park)._-Dan and Hannah Casey visited this site on 2 August from 2025-2135, observing from the roadside at the falls and from a pullout about $200 \mathrm{~m}$ west of the stream crossing. The road was under construction, so closer approach was not possible. We saw four swifts fly into the falls (one at 2042, three at 2128), indicating that it is the first new nesting site discovered for Black Swifts in Montana in more than 40 years. Figure 1 shows the approximate location where the swifts entered the falls; all four were within a 20-m section of cliff face below Going-to-the-Sun Road. Elevation at the site was 1,585 m (5,200 feet).

One entry occurred at perhaps the most likely site for a nest, just below the lip of a small (ca. $15 \mathrm{~m}$ ) plunge section of the waterfall; the other three birds flew into the wetted cliff just south of this plunge. The number of pairs and/or nests that these four individuals represent is unknown. This site should certainly be resurveyed in future years. After the road construction is completed, it will be possible to scramble below the road to a place where the falls are more easily visible, which should enable us to estimate colony size.

Mount Vaught/McPartland Mountain (Glacier Park).-Black Swifts were discovered nesting behind an unnamed falls on a headwall between these two mountains on 24 July 1962, making this site the second confirmed nesting locale for Black Swifts in Montana (see Hunter and Baldwin 1972). The site is approximately $6 \mathrm{~km}$ northwest of Avalanche Lake. On 2 August, Dan Casey looked for these falls from the road along upper McDonald Creek but concluded that they no longer existed (or, at least that no flow was present). The possibility that melting glaciers associated with global climate change result in a net loss of waterfalls, and thus a potential loss in nesting habitat for Black Swifts, is intriguing.

Lower Virginia Falls (Glacier Park).- - This site was visited by John and Kathy Hughes during mid-day on 21 August. No birds were seen.

Weeping Wall (Glacier Park)._-Dan and Hannah Casey visited this site on 2 August. The survey lasted 38 min (19452023) and was conducted from the roadside 
along the entire wetted length of the rock wall (ca. $150 \mathrm{~m}$ ). No swifts were seen during the survey. This site includes a wall about 8 $\mathrm{m}$ high with weak flows at the time we visited (although most nearby "streams" above and below this site were dry on this date). Although the site has many small niches and good aerial access, coupled with a commanding view, most niches are probably accessible to predators, there is little moss, and most of the moisture results from seeps. We believe that this site does not need further surveys. That said, the site is readily accessible and thus could easily be visited in conjunction with visits to other nearby sites.

\section{St. Mary Falls (Glacier National} Park).- - This site was visited by John and Kathy Hughes during mid-day on 21 August. No birds were seen.

Little Bitterroot (Plum Creek adjacent to Flathead National Forest)._-Visited by John and Kathy Hughes from 1905 to 2055 on 18 August. No birds were seen, but the falls appear to have suitable structure for nesting swifts.

Martin Creek (Flathead National Forest).-Dan and Susannah Casey visited these falls on 4 August from 2035-2130. No swifts were seen. This site sits within the canopy in a forested landscape and is a roughly 25-m cascade with limited aerial access and relatively easy access for predators to what niches are available. This site is highly unlikely to support Black Swifts and should not be included in future surveys.

Silver Stairs (Flathead National Forest).- This cascade-style falls along Highway 2 near Marias Pass was surveyed by Dan Casey from 1940-2134 on 3 August. No Black Swifts were seen. The falls were surveyed from the roadside and from a "trail" alongside the lower section (ca. $30 \mathrm{~m}$ vertical with no plunges or horsetail sections longer than $1 \mathrm{~m}$ or so). This "staircase" falls has numerous niches, but very few vertical faces on the lower visible portions, and profuse access to predators. Indeed, during the survey Casey watched three teenagers scrambling up the face of the falls until they were out of sight and also saw five smaller children climbing on the lower $10 \mathrm{~m}$ of the falls. It is doubtful that any suitable swift habitat occurs on this lower section, although longer plunge sections are apparently more common higher up on the falls. The site should not be emphasized in future survey efforts.

Mission Falls (Mission Mountains, Flathead Reservation)._-Jeff Marks visited the falls on 5 August between 1215 and 1300. The falls consists of a horsetail of about $20 \mathrm{~m}$ with no visible nesting niches (owing to the volume of water). This site was surveyed for Black Swifts in 1961 (Hunter and Baldwin 1962), the authors finding no swifts at Mission Falls proper but discovering a colony behind the unnamed falls on the South Fork of Mission Creek (see below). Mission Falls, and Elizabeth Falls above it, do not appear to be highly suitable for nesting Black Swifts, but if time permits it would be worth confirming this notion by observing the two sets of falls for a longer period of time toward the end of the day.

South Fork Mission Creek (Mission Mountains, Flathead Reservation).Discovery of the first known nest sites for Black Swifts in Montana occurred here in July 1961 (Hunter and Baldwin 1962). Jeff Marks visited the site from $1400-1715$ on 5 August. Access to the site involves crossing Mission Creek below Mission Falls and then bushwhacking through dense brush to emerge at the lower half of the falls. Then, one must scale a steep slope and plow 
thorough more brush to come out on a small outcrop of rock directly across from the section of falls where the swifts nest. The falls are about $60 \mathrm{~m}$ high, but the spot where the swifts nest is on a small segment with a gentle plunge of water near the top of the main falls.

At 1100, Marks saw two Black Swifts flying high above Mission Creek, heading toward the falls, as he hiked up the drainage, but he saw no swifts near the falls until a single bird arrived silently and flew directly behind a curtain of water, presumably to a nest, at 1607 (Fig. 1). Interestingly, the site Marks observed was different from the five nests originally discovered here in 1961 (see Hunter and Baldwin 1962: figure 1), although it was within a meter of nest no. 4 shown in the paper. The elevation at the site was about 1,370 m (4,500 feet). The entire falls is a complex of plunges, horsetails, fans, and cascades, and the falls in segmented and tiered. Much of it appears unsuitable for nesting swifts. This fact underscores the need to revisit some of the large falls in Glacier Park (e.g., Avalanche Lake complex) that might appear unsuitable from a distance yet contain small portions of suitable habitat used by swifts.

Another important lesson learned at this site is that swifts may arrive very quickly and quietly (or their vocalizations cannot be heard above the noise of the falls), and they will fly directly to their nests without circling the falls. Had Marks been looking in another direction for even a moment, he would have missed seeing the bird. Marks did not stay later in the day because it would have been unsafe to hike out of the site in the dark. We recommend that if this site is visited at dusk to estimate colony size, observers should spend the night somewhere in the vicinity of the falls.
Gash Creek (Bitterroot Mountains, Bitterroot National Forest)._-Jeff Marks observed this site from 1830-1925 on 22 July. Not shown on any maps, we learned of it from Sophie Osborn, who reported Black Swifts flying behind the falls in 1997 or 1998 when she was studying American Dippers (Cinclus mexicanus). The falls is on private land just south (below) of the Forest Service boundary, and access through public land requires bushwhacking about $2 \mathrm{~km}$ into a steep canyon. Marks did not see any swifts, but he was not able to stay later in the day because it would have been difficult to hike out of the site at night. The site could be easily and safely accessed from private land.

The falls consists of a plunge of about $8 \mathrm{~m}$, with water flowing into a cave-like bowl that appeared to have lots of niches behind it. The site is not typical for Black Swifts because it is at a rather low elevation $(1,250$ $\mathrm{m})$, is near the base of the mountains, does not offer a commanding view of the valley below, and is partially enclosed by conifers from above. Nonetheless, in view of Osborn's observations this site should be visited near sundown next year if permission from private landowners to access the site can be obtained.

\section{Lower Falls, Sweathouse Creek} (Bitterroot Mountains, Bitterroot National Forest)._-Jeff Marks observed this site on 21 July and again, with Patrick Toomey, on 3 August, staying until sundown. No swifts were seen. The falls is only about $12 \mathrm{~m}$ high, half of which is a plunge and the other half a horsetail. There did not appear to be nesting niches behind the plunge portion of the falls, and we conclude that Black Swifts do not nest at this site.

Upper Falls, Sweathouse Creek (Bitterroot Mountains, Bitterroot National Forest)._-Jeff Marks and Patrick Toomey 
observed this small falls (ca. $8 \mathrm{~m}$ high) from 1900-1930 on 3 August. No swifts were seen, and the site did not appear to offer any suitable nest niches. It is highly doubtful that swifts nest at this site.

Skalkaho Falls (Sapphire Mountains, Bitterroot National Forest). - Visited by Patrick Toomey from 1745-2100 on 6 August, who saw no Black Swifts. The falls is roughly $30 \mathrm{~m}$ high and consists mostly of a series of cascades. There did not appear to be much in the way of suitable nesting niches for swifts.

Hyalite Canyon complex (Gallatin National Forest).-We visited 10 falls within Hyalite Canyon proper as well as Palisade Falls near the mouth of the Flanders Creek Canyon east of Hyalite Reservoir. The sites within Hyalite Canyon range in elevation from 2,180 m (7,150 feet) at Grotto Falls to about 2,685 $\mathrm{m}$ (8,800 feet) at Alpine and S'il Vous Plait falls below Hyalite Lake; Palisade Falls is at 2,225 m (7,300 feet). Jeff Marks and Angie Kociolek visited Arch, Champagne, Grotto, Silken Skein, and Unnamed No. 1 on 8 August, staying until sundown to watch two of them (Champagne and Unnamed No. 1). On 11 August, Angie Kociolek visited Alpine, Apex, Shower, S’il Vous Plait, and Unnamed No. 2 in Hyalite Canyon and then went to Palisade Falls, which she observed from 1930-2100. Kociolek, Dan Krza, Kate Regan, and Russell Barabe returned to the canyon on 21 August, observing Alpine Falls and Unnamed No. 2 from 1900-2045. No swifts were seen.

The named falls in the Hyalite Canyon area did not seem especially suitable for Black Swifts. Most are small and are tucked amidst conifers on flat sections of the creek versus high up on slopes that offered commanding views. Two exceptions are Unnamed Falls
Nos. 1 and 2, which could not be approached closely but which appeared to have characteristics consistent with our notion of good swift habitat. We note, however, that Black Swifts appear to be very rare in this part of Montana. Indeed, we know of only one sight record for Gallatin County, a bird seen by Clifford Davis near Rockhaven in May 1962 (Skaar 1969). Given that Skaar himself never observed this species in the Bozeman area, and that it hasn't been seen in the area in the 20 years since Skaar died, the occurrence of the Black Swift as a breeder in the Gallatin Range is doubtful, despite the presence of waterfalls that may be suitable for nesting.

\section{Discussion}

Drawing on his extensive experience searching for swifts in Colorado, Knorr (1961: 168) listed five "requirements" of Black Swift nesting sites: (1) water, varying from a trickle to a torrent; (2) high relief, offering a commanding position above surrounding terrain; (3) inaccessibility to terrestrial predators; (4) darkness, such that "the sun never shines on the nest of a Black Swift"; and (5) unobstructed flyways, which are a corollary to high relief. To this we would add that the few nest sites we have seen have been behind plunges of moderate (vs. torrential) flow, and there has to be space behind the falls such that water is not pouring down onto the nest proper. The five nests observed on the South Fork of Mission Creek in 1961 exhibited Knorr's requirements, except that four of the nests received direct sunlight in late afternoon (Hunter and Baldwin 1962: 415). Black Swifts have been documented nesting in a low-relief stream gorge in Alberta (D. Cannings, pers. obs.), and if the Gash Creek site proves to be occupied by nesting swifts, it will constitute a second site that does not have high relief. 
Thus, we think of Knorr's requirements as perhaps applying to the highest-quality nesting sites for the species rather than being absolute requisites. That said, his observations will be very useful as we attempt to narrow our search to waterfalls that possess characteristics that would maximize their potential to be occupied by Black Swifts.

One of the biggest challenges we faced was not being able to closely observe sites at the best time (i.e., early evening) to maximize our chances of seeing swifts. For example, Glacier Park offers high potential for nesting colonies owing to the fact that many falls exist in the area, and swifts have been observed in the park repeatedly for many years. Yet, many of the waterfalls have no trails to them, and the park is inhabited by grizzly bears. Bushwhacking out of a remote site after sundown simply is not safe on a number of fronts. Consequently, many of the surveys in Glacier Park will involve overnight stays and perhaps arduous hikes. The same problems would apply to falls in the Mission Mountains and perhaps also to those in the Cabinet and Purcell ranges. The Bitterroot Mountains also offer high potential for nesting Black Swifts. Birds have been seen there many times in summer (Lenard et al. 2003), and small unnamed waterfalls likely occur in many of the drainages that come off this steep range.

For next year, we will request funds for a concerted effort to survey at least six highpotential and perhaps remote sites in Glacier National Park and the Bitterroot Mountains. These sites will be selected after we consult with Park Service and Forest Service biologists. As noted above, we also recommend revisiting Gash Creek to document whether swifts nest there and South Fork of Mission Creek and Haystack Creek to estimate colony size. By concentrating on a small number of sites that look especially suitable, we could make enough visits to not only document breeding, but to estimate colony size. The next step would be to set up a scheme to monitor known occupied sites for presence of swifts (and perhaps nesting success) in future years.

\section{Acknowledgments}

We thank Russell Barabe, Dick Cannings, Hannah Casey, Susannah Casey, Steve Gniadek, John Hughes, Kathy Hughes, Angie Kociolek, Dan Krza, Kate Ciari Regan, and Patrick Toomey for helping with the surveys.

\section{Literature Cited}

Altman, B. 2003. Inventorying Black Swift nesting populations at waterfalls in the Northern Pacific Rainforest Bird Conservation Region. American Bird Conservancy, Corvallis, OR. $<$ http://home.pacifier.com/ neawanna/B LSW/BLSW_pro.html>

Casey, D. 2000. Partners in Flight Draft Bird Conservation Plan Montana. Version 1.0. Montana Partners in Flight, Montana Fish, Wildlife and Parks, Kalispell, MT.

Casey, D. 2004. Coordinated bird monitoring in Montana. Special species monitoring: Black Swift. Prepared for the Montana Bird Conservation Partnership and the University of Montana. American Bird Conservancy, Kalispell, MT. .

Foerster, K. S., and C. T. Collins. 1990. Breeding distribution of the Black Swift in southern California. Western Birds 21:1-9.

Hunter, W. F., and P. H. Baldwin. 1962. Nesting of the Black Swift in Montana. Wilson Bulletin 74:409-416. 
Hunter, W. F, and P. H. Baldwin. 1972. Black Swift nest in Glacier National Park. Murrelet 53:50-55.

Knorr, O. A. 1961. The geographical and ecological distribution of the Black Swift in Colorado. Wilson Bulletin 73:155-170.

Knorr, O. A. 1993. Black Swift (Cypseloides niger) nesting site characteristics: Some new insights. Avocetta 17:139-140.

Lenard, S., J. Carlson, J. Ellis, C. Jones, and C. Tilly. 2003. P.D. Skaar's Montana
Bird Distribution, $6^{\text {th }}$ ed. Montana Audubon, Helena.

Marín, M. 1997. Some aspects of the breeding biology of the Black Swift. Wilson Bulletin 109:290-306.

Schultz, C., and R. Levad. 2002. Black Swift survey protocol. San Juan National Forest and Rocky Mountain Bird Observatory, Grand Junction, CO.

Skaar, P. D. 1969. Birds of the Bozeman latilong. Published privately, Bozeman, MT. 
Table 1. Potential Black Swift nesting sites ${ }^{\mathrm{A}}$ visited in 2004.

\begin{tabular}{|c|c|c|c|}
\hline Waterfall Name & Ownership & Latitude/Longitude (USGS quad) & Site score \\
\hline Appistoki Falls & Glacier NP & $48.482^{\circ} \mathrm{N}, 113.353^{\circ} \mathrm{W}$ (Squaw Mountain) & 18 \\
\hline Monument Falls (Avalanche Lake) & Glacier NP & $48.650^{\circ} \mathrm{N}, 113.768^{\circ} \mathrm{W}$ (Mount Cannon) & 24 \\
\hline Unnamed No. 1 (Avalanche Lake) & Glacier NP & $48.647^{\circ} \mathrm{N}, 113.767^{\circ} \mathrm{W}$ (Mount Cannon) & $20+$ \\
\hline Unnamed No. 2 (Avalanche Lake) & Glacier NP & $48.641^{\circ} \mathrm{N}, 113.774^{\circ} \mathrm{W}$ (Mount Cannon) & 25 \\
\hline Unnamed No. 3 (Avalanche Lake) & Glacier NP & $48.637^{\circ} \mathrm{N}, 113.781^{\circ} \mathrm{W}$ (Mount Cannon) & 22 \\
\hline Baring Falls & Glacier NP & $48.677^{\circ} \mathrm{N}, 113.593^{\circ} \mathrm{W}$ (Rising Sun) & 19 \\
\hline Bird Woman Falls & Glacier NP & $48.708^{\circ} \mathrm{N}, 113.747^{\circ} \mathrm{W}$ (Logan Pass) & $20+$ \\
\hline Haystack Creek & Glacier NP & $48.739^{\circ} \mathrm{N}, 113.745^{\circ} \mathrm{W}$ (Logan Pass) & 20 \\
\hline Vaught/McPartland mountains & Glacier NP & $48.679^{\circ} \mathrm{N}, 113.854^{\circ} \mathrm{W}$ (Mount Cannon) & Not scored \\
\hline St. Mary Falls & Glacier NP & $48.668^{\circ} \mathrm{N}, 113.614^{\circ} \mathrm{W}$ (Rising Sun) & Not scored \\
\hline Virginia Falls (Lower) & Glacier NP & $48.660^{\circ} \mathrm{N}, 113.613^{\circ} \mathrm{W}$ (Rising Sun) & Not scored \\
\hline Weeping Wall & Glacier NP & $48.727^{\circ} \mathrm{N}, 113.728^{\circ} \mathrm{W}$ (Logan Pass) & 17 \\
\hline Little Bitterroot & Plum Creek & $48.014^{\circ} \mathrm{N}, 114.708^{\circ} \mathrm{W}$ (Marion) & 20 \\
\hline Martin Creek & Flathead NF & $48.567^{\circ} \mathrm{N}, 114.686^{\circ} \mathrm{W}$ (Radnor) & 17 \\
\hline Silver Stairs & Flathead NF & $48.235^{\circ} \mathrm{N}, 113.525^{\circ} \mathrm{W}$ (Nimrod) & 17 \\
\hline Mission Falls & Flathead Res & $47.337^{\circ} \mathrm{N}, 113.939^{\circ} \mathrm{W}$ (Saint Marys Lake) & 22 \\
\hline South Fork Mission Creek & Flathead Res & $47.331^{\circ} \mathrm{N}, 113.945^{\circ} \mathrm{W}$ (Saint Marys Lake) & 26 \\
\hline Gash Creek & Bitterroot NF & $46.400^{\circ} \mathrm{N}, 114.237^{\circ} \mathrm{W}$ (Victor) & 21 \\
\hline Sweathouse Creek (Lower) & Bitterroot NF & $46.425^{\circ} \mathrm{N}, 114.257^{\circ} \mathrm{W}$ (Gash Point) & 24 \\
\hline Sweathouse Creek (Upper) & Bitterroot NF & $46.426^{\circ} \mathrm{N}, 114.260^{\circ} \mathrm{W}$ (Gash Point) & 15 \\
\hline Skalkaho Falls & Bitterroot NF & $46.258^{\circ} \mathrm{N}, 113.827^{\circ} \mathrm{W}$ (Burnt Fork Lake) & 20 \\
\hline Alpine Falls & Gallatin NF & $45.393^{\circ} \mathrm{N}, 110.953^{\circ} \mathrm{W}$ (Fridley Peak) & 23 \\
\hline Apex Falls & Gallatin NF & $45.396^{\circ} \mathrm{N}, 110.956^{\circ} \mathrm{W}$ (Fridley Peak) & 20 \\
\hline Arch Falls & Gallatin NF & $45.428^{\circ} \mathrm{N}, 110.961^{\circ} \mathrm{W}$ (Fridley Peak) & 20 \\
\hline Champagne Falls & Gallatin NF & $45.408^{\circ} \mathrm{N}, 110.958^{\circ} \mathrm{W}$ (Fridley Peak) & 22 \\
\hline Grotto Falls & Gallatin NF & $45.436^{\circ} \mathrm{N}, 110.964^{\circ} \mathrm{W}$ (Fridley Peak) & 20 \\
\hline Palisade Falls & Gallatin NF & $45.470^{\circ} \mathrm{N}, 110.930^{\circ} \mathrm{W}$ (Fridley Peak) & 24 \\
\hline Shower Falls & Gallatin NF & $45.397^{\circ} \mathrm{N}, 110.959^{\circ} \mathrm{W}$ (Fridley Peak) & 18 \\
\hline S'il Vous Plait Falls & Gallatin NF & $45.393^{\circ} \mathrm{N}, 110.957^{\circ} \mathrm{W}$ (Fridley Peak) & 20 \\
\hline Silken Skein Falls & Gallatin NF & $45.420^{\circ} \mathrm{N}, 110.954^{\circ} \mathrm{W}$ (Fridley Peak) & 17 \\
\hline Unnamed Falls No. 1 (Hyalite) & Gallatin NF & $45.412^{\circ} \mathrm{N}, 110.966^{\circ} \mathrm{W}$ (Fridley Peak) & 24 \\
\hline Unnamed Falls No. 2 (Hyalite) & Gallatin NF & $45.406^{\circ} \mathrm{N}, 110.962^{\circ} \mathrm{W}$ (Fridley Peak) & 25 \\
\hline
\end{tabular}

A Sites where swifts were observed are in bold. Nesting strongly suspected only at Haystack Creek and South Fork Mission Creek. 

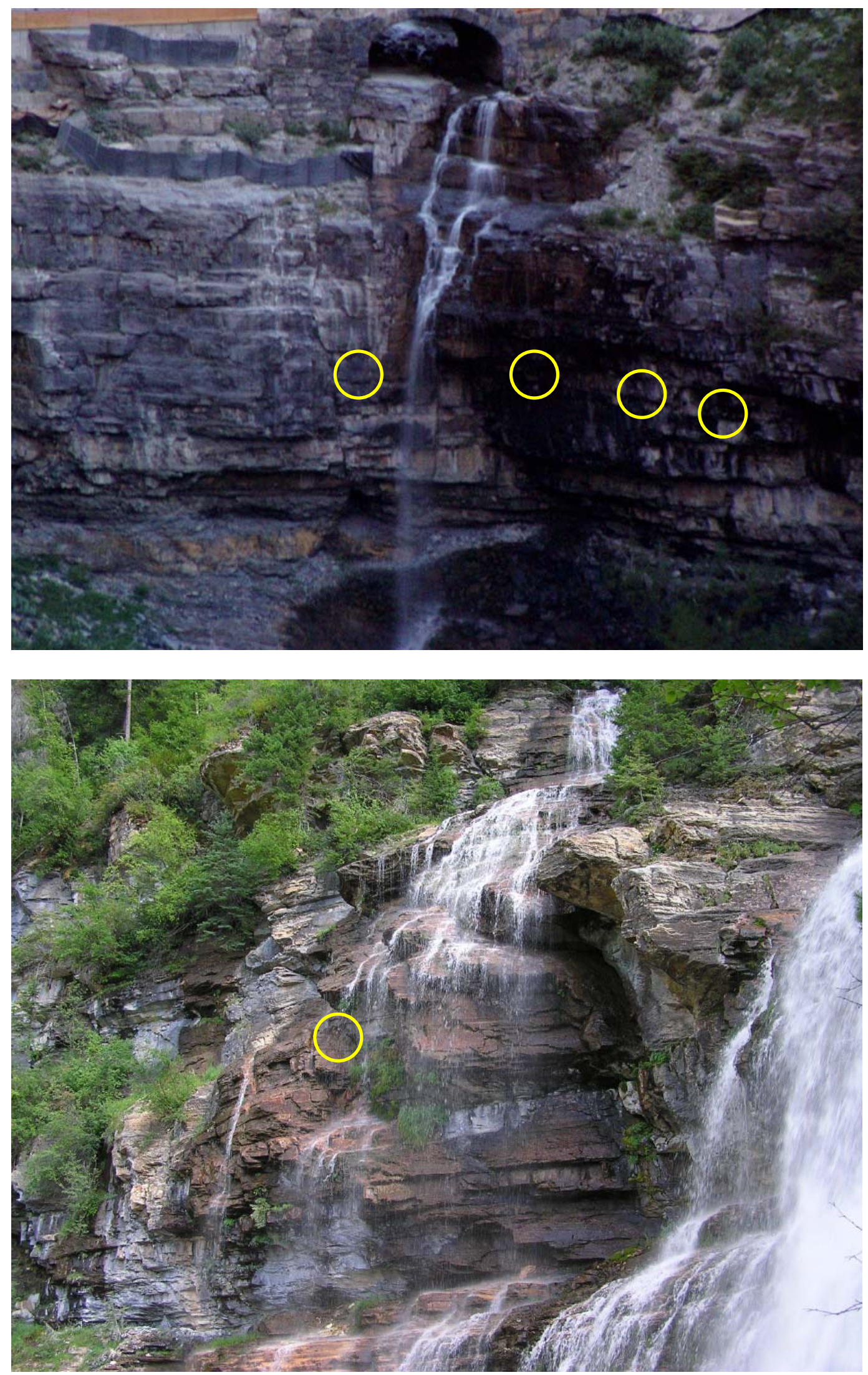

Fig. 1. Haystack Creek falls (top) and South Fork Mission Creek falls (bottom). Yellow circles denote approximate locations where single Black Swifts entered suspected nest sites on 2 August (Haystack) and 5 August (Mission) 2004. 
Appendix A. Black Swift Survey Form (instructions on back page).

Observer Name:

Date:

Begin Time:

End Time:

Your mailing and e-mail address:

Black Swifts Seen? $(\checkmark)$ Yes No. If Yes, Estimate Minimum Colony Size (\# of adults):

Number of Nests: $\_$. Number of Nestlings: _. . Nest Niche $(\checkmark)$ : Ledge Pocket Other

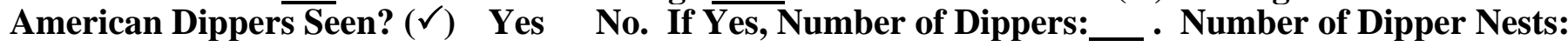

Site or Waterfall Name:

Aspect (direction falls face)

Ownership ( $\checkmark$ ): Public $\overline{\text { Private }}$

Location: USGS Quad Map:

Legal Description: Township:
Stream Name:

Elevation (top of falls):

Management Area/Owner:

County:

$\mathbf{f t}$

- UTM - Zone: $\_$S $\quad$ E:

Range:_Section:_ $1 / 4$ Section:

. N:

Directions to Falls and Best Observation Point:

Waterfall Type and Height:

Total Height of Falls_f ft Plunge: __f ft Horsetail: __ft Fan:__ft Cascade:

Segmented? $(\checkmark)$ : Yes No.

Tiered? $(\sqrt{)}$ : Yes No.

Flowing Surface Water during late summer $(\checkmark)$ :

No flowing water (1)

Flows weak (2)

Flows moderate, some spray (4)

Flows heavy, much spray (5)

Points:

Flows moderate, little spray $\overline{(3)}$

Relief (commanding view) from Top of Falls over Surrounding Terrain $(\checkmark)$ :

Points:

Falls at bottom of terrain (1) Little view from falls (2) Moderate view from falls (3)

Good view from falls (4)

Commanding view from falls over terrain (5)

Number of Suitable Nest Niches (pockets or ledges) and Accessability to Ground Predators ( $\checkmark$ ): Points:

No suitable niches present (1)

Few niches and/or all niches accessable (2)

Some niches and/or most niches accessable (3)

Many suitable niches and/or all niches inaccessable (5)

Unobstructed Aerial Access to or from Nest Niches $(\checkmark)$ :

No clear access (1)

Clear to $1 / 4$ of niches (2)

Clear to $3 / 4$ of niches (4)

Clear to all of niches (5)

Clear to $1 / 2$ of niches (3)

Points:

Shading of Nest Niches $(\checkmark)$ :

Nest niches sunlit all day (1) Sunlit >3hr/day (2)

Shaded all day (5)

Some niches and/or most niches inaccessable (4)

Moss Availability ( $\checkmark$ ):

No moss present (1)

Abundant moss (5)

Trace of moss (2) $\quad$ Scattered moss (3)

Frequent Moss (4)

Points:

Sunlit 1-3hr/day (3)

Sunlit $<1$ hr/day (4)

Total Points:

Weather, observations, comments, nests (location, height, distance from falls, presence of whitewash) etc.: 
Appendix A, contd. Instructions for field protocol

Completed Forms: Make a copy, and send original with topo map to Jeff Marks, Montana Cooperative Wildlife Research Unit, University of Montana, Missoula, MT 59812 or to Daniel Casey, American Bird Conservancy, 33 Second St. E., Kalispell, MT, 59901, no later than 30 September 2004.

Survey Methods: The probability of detecting a new Black Swift colony is highest when they are feeding young, which, in the Rocky Mountains, is mid-July to late August. The most productive time to count flying birds is the final two hours of daylight when adult swifts return to the colony to roost and feed young. Try to visit each site twice, with at least 10 days between visits. During each survey, estimate the highest number of adults visible at one time flying about or roosting on the nest cliff. Select an observation location that maximizes the view of the potential nest cliff and aerial access routes. At falls, this will usually be near the base where there is a clear view of the sky, especially in the dim light conditions just before dark. Please describe locations birds are seen roosting so they can by checked for nests in daylight. Choose weather conditions with light winds, little or no overcast, light precipitation and seasonally mild temperatures. For safety reasons, there should be two observers present at all visits, with both observers watching from the same location. Always carry a primary and backup flashlight with spare batteries in case one dies while walking out after dark. Be aware of lightening, and remember, working around wet, moss-covered cliffs is inherently dangerous, especially after dark. BE CAREFUL.

\section{Waterfall Type:}

- Plunge: water is free-falling for most of its height without coming into contact with the underlying rock.

- Horsetail: water maintains some contact with underlying rock for much of its height.

- Fan: like a horsetail, but the stream of falling water gets wider as it descends.

- Cascade: water flowing over a broad face with too many small leaps or segments to count.

- Segmented: water is divided into two or more streams falling parallel to each other.

- Tiered: the length of the water's drop is broken into distinct falls that are separated by short runs.

Black Swift Habitat Characteristics: (Please fill in your score for each of these features on the field form)

Flowing Surface Water: The most documented nesting habitat requirement is close proximity to falling water. No Black Swift nests have been found along intermittent streams, thus year-round flows appear to be required. The nest structures are usually in small cavities within the spray zone or directly behind the sheets of falling water, and are described as wet and dark. Occasionally, nests are located away from the spray zone but these are usually on ledges that are moist from other water sources.

Commanding View (relief): The second most commonly noted nesting habitat attribute is a commanding view from the nest colony over the surrounding terrain. The ability of a swift to fly straight out from the nest colony and very quickly be hundreds of feet above the valley floor appears to be very important for site occupancy. Swifts are known to nest in the bottom of deep canyons and in caves but in these cases there is usually a broad view from the nest cliff down the canyon or from the mouth of the cave.

Number of Nest Niches and Accessibility to Ground Predators: Black Swift nests are almost always built in a small pocket or ledge on a sheer face. Occupied nest niches are always inaccessible to mammalian ground predators. The placement of nests out of reach of ground predators may be an evolutionary response to low reproductive rates. All reports of Black Swift clutch sizes are of one egg only. Therefore, failure of the nest structure itself is the leading cause of reproductive failure.

Unobstructed Aerial Access: A third habitat attribute that is related to commanding views is that aerial access to the nest niche is usually free of obstructions to flight. Black Swifts appear reluctant to fly near or through tree crowns and branches to access nest niches. Therefore, screening of potential nest cliffs by trees or other debris appears to significantly reduce the likelihood that otherwise suitable nest cliffs will be occupied by swifts.

Shaded Nest Sites: Black Swift nest ledges are rarely sunlit, and then only late in the day as ambient air temperatures decline. The nest structures are invariably placed in microsites that are in deep shade the majority of the day. However, nestlings do not appear bothered by sunlight and often become more active while in direct sunlight.

Moss Availability: The nest niche often has water flowing around or in front of the opening but the nest cup itself is usually dry. Because of their dampness and darkness, the nest niches are often covered with moss and other hydrophytic plants, and due to their ready availability, swift nests are constructed almost exclusively of mosses, lichens and other fine plant material. 


\section{SECTION 3}

\section{COEUR D'ALENE SALAMANDER SURVEYS}




\title{
Coeur d'Alene Salamander Surveys in Northwestern Montana
}

\author{
Paul Hendricks \\ Montana Natural Heritage Program
}

\section{Introduction}

The Coeur d'Alene Salamander (Plethodon idahoensis) is the only plethodontid salamander known from the northern Rocky Mountains. The species has a discontinuous distribution that includes the Panhandle region of Idaho and southeastern British Columbia (Wilson and Ohanjanian 2002). In Montana, the Coeur d'Alene Salamander is found exclusively west of the Continental Divide in the five counties (Lincoln, Mineral, Missoula, Ravalli, Sanders) bordering the Idaho Panhandle, with $>80 \%$ of known locations occurring in Lincoln and Sanders counties in the extreme northwest (Maxell et al. 2003, Werner et al. 2004), although new locations continue to be discovered in the other three counties. Surveys in the 1980's documented many new locations, and revealed that the species was more widespread and abundant than previously thought (Groves et al. 1996). Nevertheless, the Coeur d'Alene Salamander remains an Animal Species of Concern in Montana (G4, S2) and is designated Sensitive on lands of the Northern Region of the U.S. Forest Service (Montana Natural Heritage Program 2004).

Following the comprehensive surveys of the late 1980's, little additional monitoring has occurred to track trends of Coeur d'Alene Salamanders across their range and to check for continued occupancy at known sites in Montana, despite recommendation that longterm monitoring include checking all sites every 10 years (Groves et al. 1996). The notable exception is an area between
Kootenai Falls and Libby (Lincoln County) where highway construction activity impacts several seeps and rock fracture zones that harbor large numbers of animals.

During 2004 several locations were revisited to determine if sites were still occupied by the salamanders. None of the sites visited in 2004 had been checked since 1995, other than the Kootenai Falls complex, which receives closer scrutiny by Forest Service personnel due to ongoing disturbance to the site.

\section{Study Area and Methods}

Surveys were conducted during 7-14 September 2004 in three counties of northwestern Montana (Lincoln, Mineral, and Sanders). A watch was maintained for potential locations to search for salamanders during drives between known sites, but few of these were encountered due to lateness of the season and relatively dry conditions when the survey was undertaken. Survey locations were a subset of those in the Montana Natural Heritage Program databases where Coeur d'Alene Salamanders were documented previously. Site descriptions in Wilson and Simon (1988) were used to help identify specific locations at each site for searches, and to determine prior conditions and what had been found then.

At sites with surface water flow, searches were first conducted during daylight. The site was checked again after dark if no salamanders were found on the first check. 
Where appropriate, surface material (stones, wood, moss mats) was overturned to look for animals in the substrate. The searches were timed, and air and water temperature recorded. Size (total length) of animals found was recorded, but none were sexed.

\section{Results}

Heritage personnel visited seven Coeur d'Alene Salamander sites in September 2004. Forest Service personnel checked an eighth site near Libby (J. Holifield personal communication). Of the four sites checked by Heritage with water flow at the surface, salamanders were found at three. Earlier in the summer, salamanders were reported at two other sites with surface flow, one of which was checked by Heritage with negative results. No surface water was present at the other three sites visited; two of these were searched (no salamanders were found). In summary, salamanders were found during summer at all historic sites with surface water present at the time of the visit. Site survey results are given below.

Kootenai Falls Complex: Lincoln County (T31NR33W, Sec. 14SW, Sec. 14SE).

Surface water present in several seepages and small waterfalls, and accumulated at the base of the exposure ( 7 September 2004: 14:10$15: 10$ ). Air temperature $62^{\circ} \mathrm{F}$, water temperature $52^{\circ} \mathrm{F}$. No salamanders found, but several were reported here earlier in the summer (B. Maxell personal communication).

Noxon: Sanders County (T26NR33W, Sec. 14SWSW). Site not checked since 1989. Surface flow present in creek. Checked area above (to south) of old secondary one-lane road in cascading reach, canopy ( $80 \%$ cover) of western redcedar, western hemlock, western larch (7 September 2004: 16:50-
17:40). Air temperature $64^{\circ} \mathrm{F}$, water temperature $51^{\circ} \mathrm{F}$. One Coeur d'Alene Salamander (total length ca. $8 \mathrm{~cm}$ ) found in wet rotten wood at edge of stream in spray zone below small fall.

Devil's Gap (Marten Creek): Sanders County (T25NR33W, Sec. 26SWSE). Site not checked since 1994. No surface or subsurface flow in moss-covered talus adjacent to and $\mathrm{S}$ of beaver dam and on $\mathrm{S}$ side of creek, open canopy (7 September 2004: 19:10-19:40). Air temperature $55^{\circ} \mathrm{F}$. No salamanders found.

Paradise (0.9 mi off Hwy 200 on S-side of Clark Fork River): Sanders County (T19NR25W, Sec. 20NESW). Site not checked since 1988. No surface flow at road cut and outcrop; mossy rocks dry at bottom of seep (8 September 2004: 16:00-16:10). No salamanders found.

Paradise (1.8 mi. off Hwy 200 on S-side of Clark Fork River): Sanders County (T19NR25W, Sec. 19NENE). Site not checked since 1988. No surface flow evident from road on moss-covered outcrops and cliffs (8 September 2004: 16:10). Site on private land and not checked.

Cascade Falls (T18NR25W, Sec. 19NESE): Sanders County. Site not checked since 1995. Substantial surface flow in creek and over falls; upper and lower falls and mosscovered spray zones checked (8 September 2004: 17:10-18:10). Air temperature $70^{\circ} \mathrm{F}$, water temperature $50^{\circ} \mathrm{F}$. One Coeur d"Alene Salamander (total length $6.5 \mathrm{~cm}$ ) found in wet rotten wood among boulders and moss below lower falls.

Trout Creek (SW of Superior): Mineral County. Site not checked since 1988. Surface water in three seeps of road cut; site now imbedded in a forest burn (9 September 
2004: 18:15-18:35). Air temperature $65^{\circ} \mathrm{F}$, water temperature $51^{\circ} \mathrm{F}$. No salamanders found. Site revisited (14 September 2004: 20:20-20:40). Air temperature $50^{\circ} \mathrm{F}$, water temperature $49^{\circ} \mathrm{F}$. Three Coeur d'Alene Salamanders found (all 9-10 cm total length), one in wet moss of south seep, one in wet talus near road at bottom of south seep, one in spray zone at base of north seep.

Libby (T31NR32W, Sec. 23): Lincoln County. This site had not been checked since 1988, prior to recent visits in June 2004 by Forest Service personnel (J. Holifield, personal communication), as part of a survey prior to highway construction along Hwy 2. On 26 June, one seep at this site was dry, but at a second wet seep two Coeur d'Alene Salamanders were active on the rock face (22:45).

\section{Discussion}

The continued presence of Coeur d'Alene Salamanders at all sites visited in 2004 with surface water flow is encouraging, and suggests that this species probably persists at most or all of the previously documented locations in Montana. Continued discovery of new locations (B. Maxell personal communication) also suggests the species is relatively secure in the state. However, many sites with potentially suitable habitat have never been surveyed and many previously surveyed sites should be rechecked in the near future following the protocols of Groves et al. (1996). Long-term monitoring of this species continues to be merited, given its restricted range in the state, apparently fragmented distribution (associated with springs and seeps), and reliance on stable subterranean water. The impacts of surface disturbances on populations of this species are still poorly understood.

\section{Literature Cited}

Groves, C. R., E. F. Cassirer, D. L. Genter, and J. D. Reichel. 1996. Element Stewardship Abstract: Coeur d'Alene Salamander (Plethodon idahoensis). Natural Areas Journal 16:238-247.

Maxell, B. A., J. K. Werner, P. Hendricks, and D. L. Flath. 2003. Herpetology in Montana: a history, status summary, checklists, dichotomous keys, accounts for native, potentially native, and exotic species, and indexed bibliography. Society for Northwestern Vertebrate Biology, Northwest Fauna Number 5. 138 pp.

Montana Natural Heritage Program. 2004. Montana Animal Species of Concern. Montana Natural Heritage Program and Montana Department of Fish, Wildlife and Parks, Helena, Montana. $13 \mathrm{pp}$.

Werner, J. K., B. A. Maxell, P. Hendricks, and D. L. Flath. 2004. Amphibians and reptiles of Montana. Mountain Press, Missoula, MT. 262 pp.

Wilson, A. G., Jr., and P. Ohanjanian. 2002. Plethodon idahoensis. Catalogue of American Amphibians and reptiles 741.1-741.4.

Wilson, A. G., Jr., and E. M. Simon. 1988. Supplementary report on the status of the Coeur d'Alene Salamander (Plethodon vandykei idahoensis) in Montana. Report to the Montana Natural Heritage Program, Helena. 65 pp. 


\section{SECTION 4}

\section{TERRESTRIAL MOLLUSK SURVEYS}




\title{
Terrestrial Mollusk Surveys in Northwestern Montana
}

\author{
Paul Hendricks \\ Montana Natural Heritage Program
}

\section{Introduction}

Montana west of the Continental Divide supports a terrestrial mollusk fauna that includes more than a dozen globally rare species endemic to the state or the northern Rocky Mountain region (Frest and Johannes 1995, 2001; Hendricks 2003). These species are currently included on the Montana Animal Species of Concern list (Montana Natural Heritage Program 2004). Habitat requirements and distributions remain poorly defined for all species, as most are reported from fewer than ten locations, with records often more than 30 years old. Thus, there is need for additional surveys to help inform current and future conservation efforts. During September 2004, in conjunction with Coeur d'Alene Salamander surveys (see Section 3), searches were also conducted for terrestrial mollusk species (snails and slugs), targeting those on the Animal Species of Concern list that are associated with mature stands of western redcedar (Thuja plicata), western hemlock (Tsuga heterophylla), and/or grand fir (Abies grandis). This forest habitat type (cedar-hemlock-grand fir) was selected because of its limited distribution in Montana, its value to the timber industry, and its increasing rarity resulting from past and continued harvest.

\section{Study Area and Methods}

Surveys were conducted during 9-14 September 2004 in three counties of northwestern Montana (Mineral, Missoula, and Sanders) that abut the Idaho Panhandle. Survey locations were not randomly chosen but instead identified by the presence of mature western redcedar while driving roads alert for suitable stands (based on size of trees and extent of canopy cover). Two of the areas visited were chosen because they were at or near historical collection sites, as listed in Hendricks (2003), and had not been surveyed in more than 40 years. Searches were carried out when conditions were cooler or moister (from rain or dew), and thereby when the target species were more likely to be active.

At locations deemed suitable for survey, 1560 minutes was spent slowly moving through the site, sorting through litter and looking under wood and rocks on the ground or imbedded in the litter. In all cases, searching was conducted by hand, often using a 3pronged hand rake to aid in turning rocks and wood. Target species were identified in the field. Museum vouchers were collected at all locations where species were found and returned to the laboratory for verification. Locations were recorded on a Garmin map76S GPS unit. Collected information was mapped and added to the Montana Natural Heritage Program Point Observation Database.

\section{Results}

Five species of terrestrial mollusk on the Animal Species of Concern list were found during the September 2004 surveys (Table 1). These included the snails Polygyrella polygyrella (Humped Coin) and Radiodiscus 
abietum (Fir Pinwheel), and the slugs

Magnipelta mycophaga (Magnum

Mantleslug = Spotted Slug), Hemphillia

danielsi (Marbled Jumping-slug), and

Prophysaon humile (Smoky Taildropper), the last species only recently recognized as occurring in Montana and added to the list. Location descriptions for each species are given below; Global (G) and Subnational/State (S) designations for each species are the current ranks provided by NatureServe and the Montana Natural Heritage Program.

Polygyrella polygyrella (Humped Coin): G2G3, S1S3

1) Prospect Creek ( 0.6 miles E of Cox Gulch Road), W of Thompson Falls, Sanders Co. (T21NR31W, Sec. 33NWNW: 3090’ elev.); 8 September 2004. N-facing aspect, canopy of grand fir, Douglas-fir, Engelmann spruce, ponderosa pine, mountain maple (total cover $=50-60 \%$ ). Ambient temperature $=56^{\circ} \mathrm{F}$, ground wet and mossy. Eight live individuals found under rotting wood (10:50-11:50). Also present were Anguispira kochi and Cryptomastix mullani. This location is up-drainage a few miles from two prior collection sites pre-dating 1950.

2) Glidden Gulch, $W$ of Thompson Falls, Sanders Co. (T21NR32W, Sec. 22NWSW: 4200’ elev.); 8 September 2004. SE-facing aspect, canopy of western redcedar, western hemlock, Engelmann spruce, Douglas-fir, alder (total cover $=40 \%$ ). Ambient temperature $64^{\circ} \mathrm{F}$, ground moist and mossy. Ten individuals (6 live, 4 shells) found under moss-covered rocks beneath ferns and beargrass (13:50-14:10). Also present were Anguispira kochi, Cryptomastix mullani, and Derocerus reticulatum.
Site is farther up the Prospect Creek drainage from Site 1.

3) East Fork Big Creek (0.8 miles above McKinney Creek), S of Haugen, Mineral Co. (T18NR30W, Sec. 8SESE: 3750’ elev.); 9 September 2004. N-facing aspect, canopy of western redcedar, grand fir, Engelmann spruce, alder (total cover $=70 \%$ ). Ambient temperature $56^{\circ} \mathrm{F}$, overcast, soil moist and mossy; near small creek draining from hillside. Three live individuals found under rocks (10:45-11:05). Also present was Anguispira kochi. Site is along forest service road above East Fork Big Creek.

4) West Fork Big Creek (beyond parking area at end of road), SW of Haugen, Mineral Co. (T19NR30W, Sec. 30SWSE: 3460’ elev.); 9

September 2004. N-facing aspect, canopy of western redcedar, western hemlock (total cover $=60 \%$ ).

Ambient temperature $62^{\circ} \mathrm{F}$, overcast, soil moist. Five live individuals found in duff-covered talus (12:0012:45). Site is at or near historical location collected by R. B. Brunson on 17 May 1964.

5) Ward Creek (ca. 0.3 miles above mouth), W of St. Regis, Mineral Co. (T18NR29W, Sec.24NENW: 2840' elev.); 9 September 2004. NWfacing aspect, canopy of western redcedar, grand fir, Engelmann spruce, mountain maple (total canopy $=65 \%$ ). Ambient temperature $65^{\circ} \mathrm{F}$, overcast, soil moist, mossy talus. Three individuals (2 live, 1 shell) found under rocks in moss-covered talus (15:35-16:15). Also present were Anguispira kochi, Cryptomastix mullani, and Radiodiscus abietum (see below). 
6) South Fork Little Joe Creek (ca. 0.2 miles above confluence with North Fork Little Joe Creek), SW of St. Regis, Mineral Co. (T17NR28W, Sec. 3NENW: 2900' elev.); 9 September 2004. SE-facing aspect, canopy of western redcedar, grand fir (total canopy $=60 \%$ ). Ambient temperature $65^{\circ} \mathrm{F}$, overcast, soil moist, mossy slope. Six individuals (5 live, 1 shell) found under duffcovered rocks (16:45-17:00).

Radiodiscus abietum (Fir Pinwheel): G3, S2S3

1) Ward Creek (ca. 0.3 miles above mouth), W of St. Regis, Mineral Co. (T18NR29W, Sec.24NENW: 2840' elev.); 9 September 2004. NWfacing aspect, canopy of western redcedar, grand fir, Engelmann spruce, mountain maple (total canopy $=65 \%$ ). Ambient temperature $65^{\circ} \mathrm{F}$, overcast, soil moist, mossy talus. One shell found under rock in mosscovered talus (15:35-16:15). Also present were Anguispira kochi, Cryptomastix mullani, and Polygyrella polygyrella (see above).

Magnipelta mycophaga (Magnum Mantleslug = Spotted Slug): G3, S1S3

1) West Fork Petty Creek (ca. 5 miles above confluence with main Petty Creek), S of Alberton, Missoula Co. (T14NR23W, Sec. 30NWSE: 4230' elev.); 14 September 2004. NWfacing aspect, canopy of western redcedar, Douglas-fir, subalpine fir (total canopy $=60 \%)$. Ambient temperature $50^{\circ} \mathrm{F}$, overcast and raining, soil and duff wet. Eleven individuals found under wet rotting bark and wood on ground, one under a duff-covered rock (12:10-13:10), in a 30 X $30 \mathrm{~m}$ area.

Hemphillia danielsi (Marbled Jumping-slug): G1G3, S1S3

1) Dry Creek (ca. 0.1 miles below Ann Arbor Gulch), W of Superior, Mineral Co. (T17NR28W, Sec. 35SESE: 3650' elev.); 14 September 2004. Level bench above creek, canopy of western redcedar, Douglasfir (total canopy $=50 \%$ ). Ambient temperature $50^{\circ} \mathrm{F}$, overcast, soil and duff wet. One individual found under wet bark and wood (15:50-16:50). Also present were Anguispira kochi, Cryptomastix mullani, and Prophysaon humile (see below).

Prophysaon humile (Smoky Taildropper): G1G2, S1S2

1) Dry Creek (ca. 0.1 miles below Ann Arbor Gulch), W of Superior, Mineral Co. (T17NR28W, Sec. 35SESE: 3650’ elev.); 14 September 2004. Level bench above creek, canopy of western redcedar, Douglasfir (total canopy $=50 \%$ ). Ambient temperature $50^{\circ} \mathrm{F}$, overcast, soil and duff wet. Two individuals found under wet bark and wood (15:5016:50). Also present were Anguispira kochi, Cryptomastix mullani, and Hemphillia danielsi (see above). 
Table 1. Mollusk species found during the 2004 surveys; 2004 locations are the number of sites where the target species was found.

\begin{tabular}{|l|l|c|c||}
\hline \multicolumn{1}{|c|}{ Species } & \multicolumn{1}{|c|}{ Common Name } & $\begin{array}{c}\text { Known Montana } \\
\text { Locations }^{1}\end{array}$ & $\begin{array}{c}\text { 2004 Locations } \\
\text { (\# New Locations) }\end{array}$ \\
\hline \hline Polygyrella polygyrella & Humped Coin & 4 & $6(5)$ \\
\hline Radiodiscus abietum & Fir Pinwheel & 13 & $1(1)$ \\
\hline Magnipelta mycophaga & Magnum Mantleslug & 6 & $1(1)$ \\
\hline Hemphillia danielsi & Marbled Jumping-slug & 5 & $1(1)$ \\
\hline Prophysaon humile & Smoky Taildropper & 1 & $1(1)$ \\
\hline
\end{tabular}

${ }^{1}$ Hendricks 2003

\section{Discussion}

Finding ten total locations (nine of which were new) of five globally rare mollusk species during this brief survey indicates that more locations of each species are likely to be found in northwest Montana in the future. A comprehensive survey to more-fully document their distributions and habitat associations is desirable; an inventory protocol to obtain this information is in the process of being developed and implemented on Forest Service lands in Region 1. Given the limited knowledge regarding all of these species (see Hendricks 2003), any survey effort can provide valuable information, even if only negative data is acquired from locations where no target species are found, so long as surveys are undertaken when conditions are cool and humid, and therefore ideal for finding terrestrial mollusks active on or near the ground surface.

The five terrestrial mollusk Species of Concern in Montana that were documented during this survey are considered in need of additional documentation or listed as "Sensitive" (reasonably well-known habitat requirements, small range, few known sites, appear to be decreasing, have recognized threats to known sites) in adjacent Idaho (Frest and Johannes 2001). The cedarhemlock-grand fir forest habitat occupied by these species in western Montana has diminished in extent over the past century, due to timber harvest and other disturbances, and continues to be threatened by similar events. Nevertheless, some populations continue to be present in areas of limited disturbance. For example, the West Fork of Big Creek continues to support a population of Polygyrella polygyrella 40 years after its discovery (see Site 4 above), even though much of the area has experienced logging activity. However, the area of extent of these populations, and the number of individuals comprising them, are not known.

Retention of some mature or old growth forest with a relatively closed canopy appears to be of primary importance for the persistence of rare mollusks at all of the 2004 sites. Of concern, though, is how fragmented many populations of these rare mollusks have become, due to complete loss of mature forest habitat or the creation of barriers to dispersal along valley bottoms and watercourses where mature and old-growth cedar-hemlock-grand fir forest is found. Minimum habitat patch size requirements of these rare mollusk species and their ability to persist over the long-term in fragmented landscapes are unknown. Thus, protection of the remaining cedar-hemlock-grand fir forest in Montana should be a high priority for the conservation of the suite of rare mollusk species associated with it. 


\section{Literature Cited}

Frest, T. J., and E. J. Johannes. 1995. Interior Columbia Basin mollusk species of special concern. Final Report to Interior Columbia Basin Ecosystem Management Project. Deixis Consultants, Seattle. 274 pp.

Frest, T. J., and E. J. Johannes. 2001. An annotated checklist of Idaho land and freshwater mollusks. Journal of the Idaho Academy of Science 36:1-51.
Hendricks, P. 2003. Status and conservation management of terrestrial mollusks of Special Concern in Montana. Report to Region 1, U.S. Forest Service. Montana Natural Heritage Program, Helena. $67 \mathrm{pp}+$ appendices.

Montana Natural Heritage Program. 2004. Montana Animal Species of Concern. Montana Natural Heritage Program and Montana Department of Fish, Wildlife and Parks, Helena, Montana. $13 \mathrm{pp}$. 


\section{SECTION 5}

\section{PLUM CREEK OWL AND MOLLUSK SURVEYS}




\section{Plum Creek Forest Owl Monitoring}

\section{PlumCreek}

\section{Objectives:}

1. Obtain information on the presence and distribution of owl species in NW Montana Plum Creek landscapes.

2. Obtain information on habitat associations of owls in managed landscapes.

3. Partner with agencies and organizations to provide data for cooperative statewide monitoring efforts.

\section{Focus Species and State Status:}

Flammulated owl, northern pygmy owl, northern saw-whet owl, barred owl, western screech owl. All are cavity nesters (barred owls use stick nests as well). The flammulated owl is a Level-1 Montana Partners in Flight priority species.

\section{Focus Habitats:}

For 2003 sampling, initial focus will be on low and mid-elevation ( 3000 to $4000 \mathrm{ft}$ ) ponderosa pine dominated (or mixed) forest areas. Areas will encompass a mix of structural stages, riparian areas, and some deciduous types. Sampling areas will be on the xeric end of site types to increase the probability of encountering flammulated owls.

\section{Focus Areas:}

Based on field knowledge, forester experience, and stand inventory queries, three potential areas were identified for 2003 sampling: Thompson River Bend area, Pleasant Valley, and the Lake Mary Ronan area.

\section{Methods:}

Survey stations are located along forest roads at $1 / 2$ to 1 mile intervals. Two visits were completed (except for Lake Mary Ronan); one in late-March /early-April (for most owl species) and the second in mid- to late-June (for flammulated owls). Time at each station totaled 8:00 minutes. A 3 minute silent listening period began the survey at each station (per Guidelines for Nocturnal Owl Monitoring in North America, March 2001, L. Takats et al.) followed by an active broadcast calling period. The broadcast protocol used a megaphone/walkman setup to playback the following species and listening periods for the March/April surveys: 0:30 sec of northern pygmy owl; 1:00 min listening period; 0:30 sec northern saw-whet owl; 1:00 min listening period; 0:30 sec barred owl; 1:30 min listening period. The June survey broadcast only flammulated owl, in three separate periods with subsequent listening periods, as in the pattern described above. An owl survey database was developed detailing station survey timing, type and bearing of responses, weather conditions, etc. for each survey. Station locations are documented on hardcopy maps, recorded with a GPS, and later mapped into a GIS. 2003 was a pilot year to further identify sampling areas and test protocols. Surveys are planned for future years. Additional spot surveys or monitoring visits were conducted at specific sites where owl nests were reported by others.

\section{Cooperative Partners:}

Survey areas, protocols, and results were coordinated and shared with Montana Fish, Wildlife, and Parks (Kristi Dubois, Dwight Bergeron), Montana Bird Conservation Partnership/Montana PIF (Dan Casey, ABC 
and Jock Young, UM), Montana Natural Heritage Program (John Carlson), Lost Trail National Wildlife Refuge (Ray Washtak and Lindy Garner, USFWS), and the Owl Research Insititute (Denver Holt).

The Montana Natural Heritage Program used Plum Creek efforts (time and materials) as federal funding match to support State Wildlife Grants used in their statewide monitoring program.

\section{Results}

Survey Effort

Approximately 40 miles of road transects were surveyed. Early spring surveys were conducted between March 25 and April 2 and consisted of 52 total stations among the 3 study areas. Late spring surveys were conducted between June 18 and June 29 and consisted of 33 stations among only 2 of the 3 study areas. The Lake Mary Ronan site was not surveyed in late spring. Surveys typically started at dusk and ended between 2223hr and 0132hr.

\section{Owl Detections}

During the early spring surveys, a total of 4 species of owls were detected at 20 of the 52 stations, for an overall early spring station response rate of 38\%. Twenty-seven individual owls were detected (multiple owls were detected at some stations). No owls were detected at any of the 33 stations surveyed in the late spring. Species detected included: 12 northern saw-whet owls (NSWO), 10 great horned owls (GHOW), 4 long-eared owls (LEOW), and 1 northern pygmy owl (NOPO). The Pleasant Valley survey detected 13 responses of 2 species (NSWO, GHOW), the Thompson River survey detected 5 responses of 2 species (LEOW, NSWO), and the Lake Mary Ronan survey detected 9 responses from 4 species (NSWO, GHOW, LEOW, NOPO).

\section{Owl Response Statistics}

To evaluate the survey protocol's silent listening and playback methods, the time from the start of a survey at a station to when an owl responded was recorded. The mean response time for all 27 individual owls detected was 3.0 minutes (little variation among study areas: 2.9, 2.8, $3.2 \mathrm{~min}$ ). However, this metric could be misleading, as about half the owl responses were detected immediately upon exiting the vehicle. A comparison of owl responses before and after the 3 minute silent listening period showed that generally half the owl responses occurred during the silent period and half during the playback periods (before/after percent ratios among the study areas: 54:46; $60: 40 ; 44: 56)$. This may support use of the playback method as a means to elicit owl responses to meet this project's monitoring objectives.

Survey Area Habitat Descriptions

All survey areas were similar in elevation (range: $3200 \mathrm{ft}$ to $4000 \mathrm{ft}$ ) and general forest habitat characteristics. The primary forest habitat in the survey areas included a Douglas-fir/Ponderosa Pine type with some Western Larch. The age and structural characteristics varied throughout the surveys and included a mix of early and midsuccessional stands to older mature stands. Canopy closure also varied, but generally was dominated by more open canopy stands. Vegetation complexity varied from single layer to multi-layered stands. Differences among study areas: portions of the Pleasant Valley survey were on or adjacent to grass meadow habitats of the Lost Trail Refuge; portions of the Thompson River survey were adjacent to the river riparian corridor that included shrub and deciduous tree components and portions were on or adjacent to cattle pastures in the valley bottom; portions of the Lake Mary Ronan survey were adjacent to cattle pastures. The 
inclusion of agricultural and meadow habitats may explain the long-eared owl detections.

Additional Spot Surveys and Monitoring

Visits

Three additional spot surveys were conducted to check reports of potential great gray owl nesting sites:

Elk Meadows (Boles Ck near Seeley Lake) Biologists from the Rocky Mountain Research Station reported a large gray owl and potential juveniles at this site in August of 2002. Broadcast calls of great gray owls were played intermittantly for $1.5 \mathrm{hrs}$ during daytime reconnaissance of the area on July 23, 2003. No detections.

Proctor (Lk Mary Ronan) - A Plum Creek forester reported seeing a great gray owl along the paved road to Proctor. Broadcast calls of great gray owls were played at night in the area on April 2, 2003. No detections. Pleasant Valley (near Lost Trail NWR) - A Plum Creek forester discovered an active great gray owl nest. A followup visit on May 23, 2003 confirmed an adult in incubation posture on a nest in a forked-top 11 inch $\mathrm{DBH}, \sim 60 \mathrm{ft}$ tall ponderosa pine (see attached pictures). A subsequent visit on June 19, 2003 found the nest partially blown out of the fork top. One adult was observed in the immediate area, but no signs of juveniles were found. The nest stand and surrounding area is an intermediate age Douglas-fir/lodgepole pine forest stand with some western larch and ponderosa pine. The area has been selectively harvested multiple times in the past. The current stand is multistoried with western larch, Douglas-fir, and lodgepole pine seedlings and saplings in the understory. Canopy cover is patchy due to tree clumps and small openings. The nest stand is scheduled for selective harvest in the fall of 2003. The nest tree will be retained. The harvest prescription will result in an intermediate age, multi-storied stand with a diverse tree species composition. Monitoring of the nest site will occur in 2004.
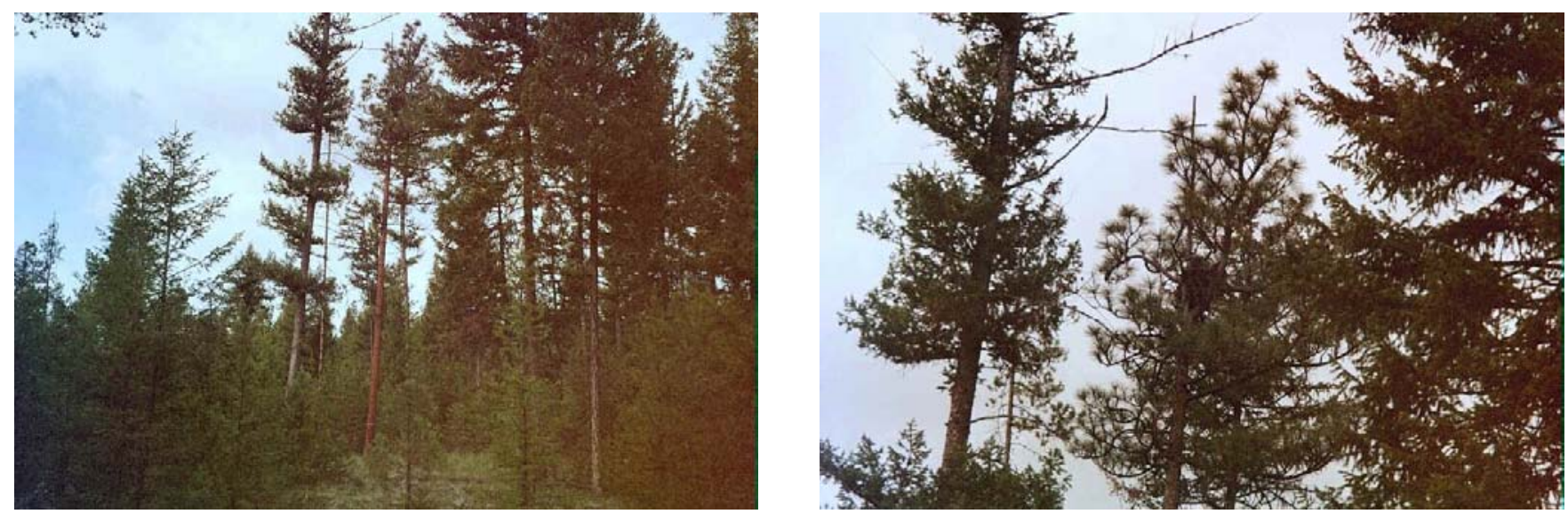

Pictures 1 \& 2: Pleasant Valley great gray owl nest site. 


\section{然 \\ PlumCreek}

\section{Plum Creek Invertebrate Monitoring}

\section{Objectives:}

1. Obtain information on the presence and distribution of globally imperiled invertebrates (carinate mountainsnail and spotted slug) in NW Montana Plum Creek landscapes.

2. Obtain information on habitat associations of these invertebrates in managed landscapes.

3. Partner with the Montana Natural Heritage Program to provide data for cooperative monitoring efforts, including experimenting with sampling techniques.

\section{Focus Species and Status:}

Carinate Mountainsnail (Oreohelix elrodi) and Spotted Slug (Magnipelta mycophaga). Both species are listed by the Natural Heritage Program and NatureServe as either globally critically imperiled (G1) or globally imperiled (G2).

\section{Focus Areas:}

For 2003 sampling, initial focus was on experimenting with sampling techniques at known Plum Creek sites or in their vicinity. Mountainsnail sites investigated were at Lion Creek and Goat Creek in the Swan Valley. Spotted slug sites sampled included Deer Creek near Missoula and the Thompson River near Bend. Habitats of initial focus were riparian areas and moist talus or rocky soil types at the known sites or adjacent vicinity. The focus species were recently found at the Lion, Goat, and Thompson Bend sites and this offers the opportunity to test sampling methods. The Deer Creek record is decades old and the exact location along the upper drainage is not precisely known.

\section{Methods:}

Survey methods included a mix of timecontrained searching and coverboard surveys. Time-constrained surveys were used to check under rocks, logs, and other cover objects in moist areas within the riparian zones or rocky substrates. Time of capture since survey start, total time searching, and general site conditions will be recorded (air and soil temperatures, recent precipitation, etc.). Electronic temperature recorders (Hobo or Tidbit types) may be available to monitor seasonal variations at occupied sites or under coverboards. Capture locations, sampling sites, and transect beginning and end points will be GPS'd. Coverboard sampling used $40 \mathrm{~cm}$ square, $3 / 4$ inch plywood boards laid on the ground along a transect in the riparian zone. Transect length and coverboard intervals were variable. Coverboards were deployed in late Spring and Summer and checked during the Fall. Coverboards were left in the field and will be visited in 2004 .

\section{Cooperative Partners:}

Survey areas, protocols, and results were coordinated and shared with the Montana Natural Heritage Program (MT NHP; John Carlson, Paul Hendricks). Plum Creek efforts (time and materials) will be used as match by MT NHP for federal funding.

\section{Results:}

Coverboard Surveys

See Attachment 1 for photos of the sites. Deer Creek, Missoula - Twenty coverboards were deployed at this historical spotted slug site on May 1, 2003. Ten boards were deployed in the riparian area below the main 
road bend in T12, R18, Section 7 and ten boards deployed in the riparian area and adjacent upland forest in T13, R18, Section 32. The riparian area is comprised of dense shrubs and scattered Englemann spruce. A recent tree clearing of a powerline right-ofway that crosses Deer Creek at the Section 7 coverboard site has resulted in several spruce and other trees being cut and left on the ground. Upland forests are an intermediateage Douglas-fir/ponderosa pine type. Both sites are in the generally flat riparian zone and range between 3900 and $4200 \mathrm{ft}$ elevation. The coverboards were checked on September 29, 2003. Weather conditions were $100 \%$ clear, warm $70 \mathrm{~F}$, light breeze. The last rain was $\sim 1 \frac{1}{2}$ weeks prior. Ground temperature was $56 \mathrm{~F}$. No target species were observed. However, conditions under many of the coverboards were moist and several other slug and snail species were observed under the boards, either attached to the underside or on the ground surface.

Thompson River, Bend - Twenty coverboards were deployed at this spotted slug site on June 18, 2003, in the riparian area on both sides of the bridge crossing at mile marker 27 (T24, R27, Section 12). This is also the area where the ACM road and County road intersect. This spotted slug site was discovered incidentally in 1999. The site is at $\sim 3200 \mathrm{ft}$ elevation and is generally flat. The riparian area is dominated by shrubs and reed canary grass and transitions to a mature and intermediate-age Douglasfir/ponderosa pine forest stand. The coverboards were checked on October 10, 2003. Weather conditions were 70\% overcast, intermittant rain/sleet, cool $\sim 32 \mathrm{~F}$, calm. Ground temperature was $36.9 \mathrm{~F}$. No target species were observed. However, conditions under the coverboards were moist and several other slug species and earthworms were observed under the boards, either attached to the underside or on the ground surface.

Lion Creek, Swan Valley - Twenty coverboards were deployed at this carinate mountainsnail site on July 1, 2003; 10 boards adjacent to the Lion Creek riparian area and 10 boards in a boulder field at the base of a slope (T22, R17, Section 13). This carinate mountainsnail site was discovered in 2001. Several broken carinate mountainsnail shells were observed during deployment in the boulder field, on the ground surface between rocks and boulders. The Lion Creek Trail traverses through this boulder field. This area was part of a selective timber harvest in 2002 that resulted in a dense, closed-canopy riparian stand along Lion Creek and a more open shelterwood stand in the uplands leading to the boulder field. The surrounding forest type is a Douglasfir/western larch stand with some ponderosa pine. Elevation is $\sim 3800 \mathrm{ft}$, the boulder field has a southern aspect, and the riparian area is generally flat. The boulder field has scattered trees ( $<10 \%$ canopy cover) and $\sim 30 \%$ shrub cover comprised of maple, false azalea, current, and huckleberry. The coverboards were checked on October 22, 2003. Weather conditions were clear, warm $50 \mathrm{~F}$, and calm. There were several days of intermittant rain prior the site visit. Ground temperature was 57.9 F. Under coverboard \#9 in the boulder field, a perfectly intact carinate mountainsnail shell (no live animal) was found on the ground surface in the middle of the board. This specimen was collected.

\section{Time-constrained Surveys}

Deer Creek, Missoula - A time-constrained survey was conducted on May 1, 2003 by Paul Hendricks (MT NHP), Ron Steiner (Plum Creek), and Henning Stabins (Plum Creek) at the $\sim$ historical spotted slug site. See above coverboard survey for a site description. Weather conditions were 100\% 
overcast, $\sim 50 \mathrm{~F}$, calm. Rain had occurred the previous day and the soil was saturated. Two hours (6 person hours) were spent surveying the Section 7 coverboard area and $\sim 1$ hour (3 person hours) were spent surveying the Section 32 coverboard area; no target species were observed. Slugs and snails were surface active, including observations of Allogona ptycophora, Oreohelix strigosa, Cryptomastix mullani, and Vritina spp.

Goat Creek, Swan Valley - A timeconstrained survey targeting the carinate mountainsnail was conducted on October 22, 2003, on the slope north of the main road in T23, R17, Plum Creek Section 11, just north of the removed bridge over Goat Creek. This area is in the vicinity of a known occupied carinate mountainsnail site on USFS land. Weather conditions were clear, $\sim 70 \mathrm{~F}$, lite breeze. Rain had occurred in the previous sevaral days. Ground surface temperature was $57.9 \mathrm{~F}$. One person hour was spent surveying the area, spot searching cover objects, talus, and the duff layer. No target species were observed; however, a live snail species was observed surface active. The slope searched is an intermediate-age Douglas-fir stand with patchy canopy cover ( 40\%), lots of openings, and a southern aspect. Elevation is $\sim 4000 \mathrm{ft}$. The soil substrate is a boulder/talus/soil mix. Above the site is an old burn area.
Incidental Observations

Rand Creek, Kalispell - A spotted slug was incidentally found during other monitoring work. Observation details are below. Observer: Henning Stabins

Date: September 11, 2003

Location GPS: UTM Zone 11, 677109 5347723 Datum: NAD 83, Units: feet Location legal: Township 29 North, Range 24 West, Section 23, Southeast quarter Location general: about 3 miles north of Ashley Lake

County: Flathead

Ownership: Plum Creek

Drainage: upper tributary to Rand Ck, which drains into Ashley Lake

Elevation: $5000 \mathrm{ft}$

Site description: Talus/scree slope below $\sim 100-150 \mathrm{ft}$ vertical rock cliff. Scattered moss and duff covered the surface rock where the slug was observed. There was no canopy cover above the site. The surrounding stand is a young, pole-sized Douglas-fir stand with scattered larger Douglas-fir and Western Larch. The area has been recently selectively harvested. No water sources are immediately nearby. Recent weather: There had been scattered, light rain in the area over the previous several days.

Voucher specimen: The single individual found was provided to Bill Leonard for use in a DNA genetics study of the species. Species confirmation: Paul Hendricks, MT NHP, confirmed the specimen's identification. 


\section{Attachment 1 - Invertebrate Monitoring Site Photos}
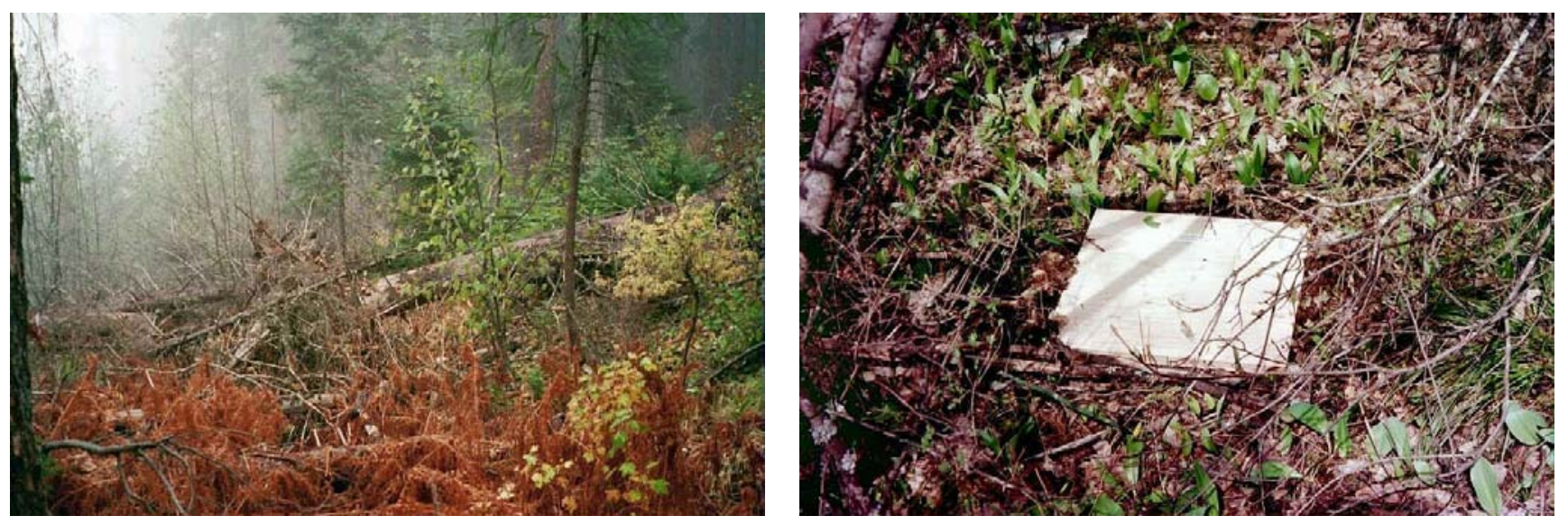

Deer Creek spotted slug coverboard site, 2003.

Rand Creek spotted slug site, 2003.
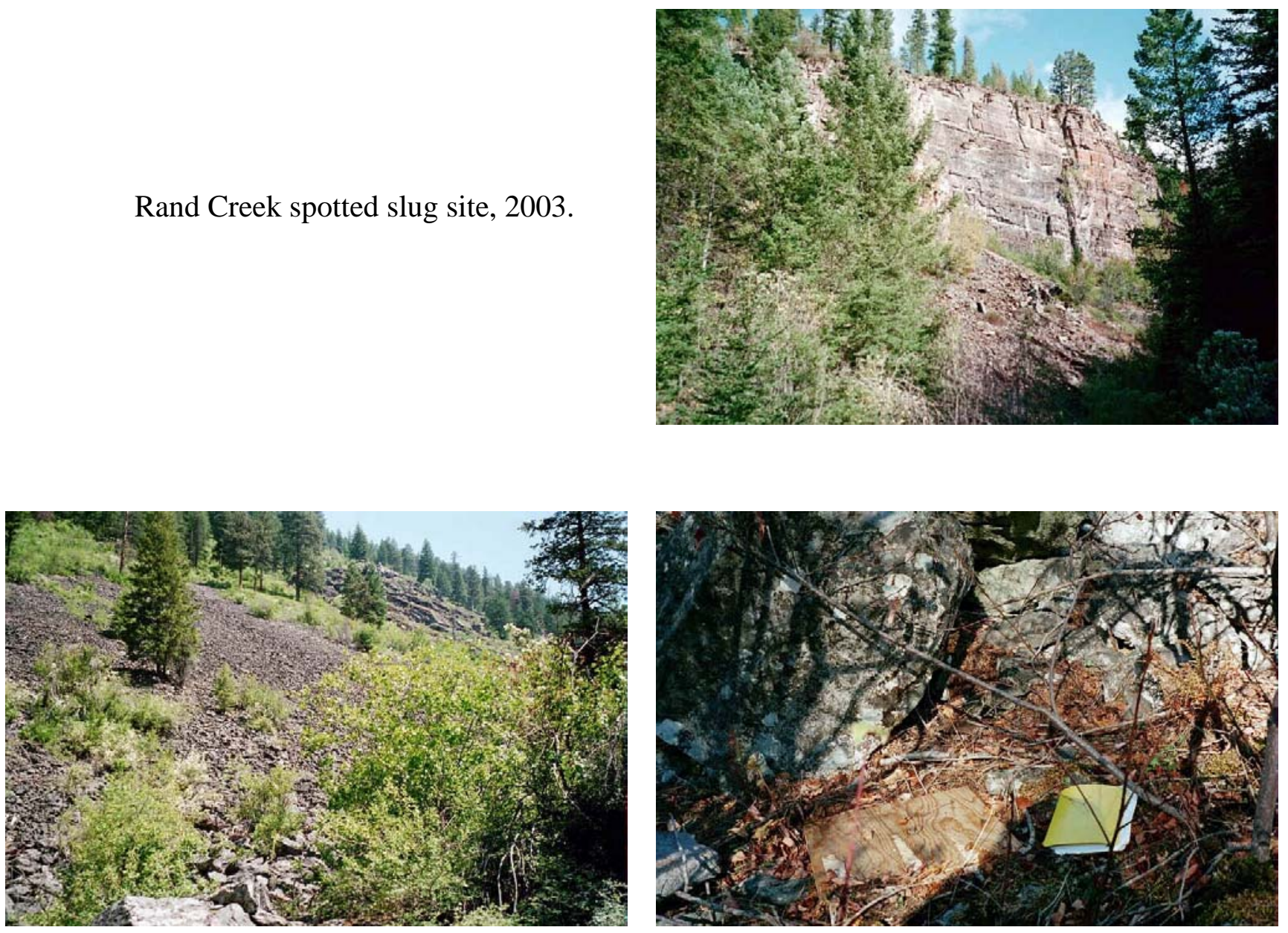

Lion Creek carinate mountainsnail coverboard site, 2003. 